\title{
Main bioactive phenolic compounds in marine algae and their mechanisms of action supporting potential health benefits
}

\author{
C. Jimenez-Lopez ${ }^{\mathrm{a}, \mathrm{b}}$, A.G. Pereira ${ }^{\mathrm{a}, \mathrm{b}}$, C. Lourenço-Lopes ${ }^{\mathrm{a}}$, P. Garcia-Oliveira ${ }^{\mathrm{a}, \mathrm{b}}$, L. Cassani $^{\mathrm{c}}$, \\ M. Fraga-Corral ${ }^{\mathrm{a}, \mathrm{b}}$, M.A. Prieto ${ }^{\mathrm{a}, *}$, J. Simal-Gandara ${ }^{\mathrm{a}, *}$ \\ ${ }^{\mathrm{a}}$ Nutrition and Bromatology Group, Analytical and Food Chemistry Department, Faculty of Food Science and Technology, University of Vigo, Ourense Campus, E-32004 \\ Ourense, Spain \\ ${ }^{\mathrm{b}}$ Centro de Investigação de Montanha (CIMO), Instituto Politécnico de Bragança, Campus de Santa Apolonia, 5300-253 Bragança, Portugal \\ ${ }^{\mathrm{c}}$ Research Group of Food Engineering, Faculty of Engineering, National University of Mar del Plata, RA7600 Mar del Plata, Argentina
}

\section{A R T I C L E I N F O}

\section{Keywords:}

Phenolic compounds

Algae

Extraction techniques

Bioactivities

Industrial applications

Chemical compounds studied in this article: Phloroglucinol (PubChem CID359)

Gallic acid (PubChem CID370)

Ferulic acid (PubChem CID445858)

Sinapic acid (PubChem CID637775)

Catechin (PubChem CID9064)

Catechin gallate (PubChem CID6419835)

Epigallocatechin (PubChem CID72277)

Eckol (PubChem CID145937)

Triphloroethol A (PubChem CID21626545)

Eckstolonol (PubChem CID10429214)

\begin{abstract}
A B S T R A C T
Given the growing tendency of consumers to choose products with natural ingredients, food industries have directed scientific research in this direction. In this regard, algae are an attractive option for the research, since they can synthesize a group of secondary metabolites, called phenolic compounds, associated with really promising properties and bioactivities. The objective of this work was to classify the major phenolic compounds, compare the effectiveness of the different extractive techniques used for their extraction, from traditional systems (like heat assisted extraction) to the most advance ones (such as ultrasound, microwave or supercritical fluid extraction); the available methods for identification and quantification; the stability of the enriched extract in phenolic compounds and the main bioactivities described for these secondary metabolites, to offer an overview of the situation to consider if it is possible and/or convenient an orientation of phenolic compounds from algae towards an industrial application.
\end{abstract}

\section{Introduction}

Algae, fruit, vegetables, and other edible plant are natural sources of phytochemical compounds (Acosta-Estrada, Gutiérrez-Uribe, \& SernaSaldívar, 2014). Once introduced in usual diet, phytochemicals exert physiological effects in humans, and for this reason they are also called bioactive compounds. Some examples of beneficial phytochemical compounds are vitamins, carotenoids (lycopene, $\beta$-carotene, and xanthophylls) and phenolic compounds (Komes et al., 2011).

These functional phytochemicals can be divided into two major groups: primary metabolites and secondary metabolites. Primary metabolites, namely carbohydrates, amino acids, lipids, and nucleic acids, are responsible for the development and growth of organisms. Secondary metabolites, on the other hand, are a group of compounds that, while not essential, give plants the ability to survive and overcome many obstacles (i.e. adverse weather, herbivory), and allow them to interact and adapt to their surroundings; thus, the same plant species growing in different locations may have different concentrations of compounds, or even different compounds in their constitution (Azmir et al., 2013; Lobo \& Lourenço, 2007; Santos, Abreu, \& Saraiva, 2016).

Focusing on phenolic compounds, they constitute a large and diversified group of secondary metabolites found mainly in plants, although other organisms also can synthesize them, such as algae. Understanding the mechanisms of action of these compounds and their interaction with the human body become relevant due to their multiple and beneficial health effects (Barbosa-Pereira et al., 2014). From a chemical point of view, phenolic compounds are formed by a structural core based on a hydroxyl group bonded directly to a phenol, which gives them the ability to capture free radicals, reactive oxygen species and chelated metal ions (Silva, 2013). Those phenolic compounds that

\footnotetext{
* Corresponding authors.

E-mail addresses: mprieto@uvigo.es (M.A. Prieto), jsimal@uvigo.es (J. Simal-Gandara).
} 
present more than one phenolic ring in their structure are called polyphenols, and they are synthesized in nature as response to environmental harmful stimuli such as UV radiation, pathogen attacks and insects or wounds (Dias, Sousa, Alves, \& Ferreira, 2016; Lopes et al., 2018). The different classes and subclasses of polyphenols are usually based on their chemical structures, what refers to the number of phenolic rings they possess and the structural elements bonded to these rings. In this context, the main groups of phenolic compounds are: phenolic acids, coumarins, flavonoids, stilbenes, tannins, lignans and lignin (Costa et al., 2013; Silva, 2013). They are associated with very diverse biological activities beneficial to health, and are present in numerous and abundant species of seaweed, especially, in the group of brown algae (Fernando, Nah, \& Jeon, 2016).

Currently, the discovery, development and market launch of new natural products that can be used as functional ingredients is becoming very important, since those natural metabolites could replace the synthetic ones, associated with several health problems or disorders. Undoubtedly, algae represent a natural source of products of interest, such as phenolic compounds (Al-Saif, 2014). These compounds are present in most classes of algae (Liu, Hansen, \& Lin, 2011), and participate in various survival processes, such as defense and protection against different factors, whether they are abiotic, such as ultra-violet (UV) radiation, or biotic, such as the attack of pathogenic microorganisms or other living beings. Most of these compounds show also biological functions such as antioxidant or antimicrobial properties. Several studies have reported that there is a correlation between the number of phenolic compounds present and the antioxidant potential that an alga shows (Klejdus, Plaza, Snóblová, \& Lojková, 2017).

The huge diversity of algae refers not only to phytoplankton, which is considered a microalga, but also to macroalgae or seaweed, so, in total, more than 11,000 different species are known. As a general classification, phytoplankton is made up of diatoms (Bacillariophyta), dinoflagellates (Dinophyta), green and yellow-brown flagellates (Prasinophyta, Prymnesiophyta, Cryptophyta, Chrysophyta, and Rhaphidiophyta) and blue-green microalgae (Cyanophyta). On the other hand, macroalgae are classified into three large groups: green algae (Chlorophyta), brown algae (Phaeophyta) and red algae (Rhodophyta), depending on the types of pigments they contain, which allows them to inhabit at different depths (Sithranga Boopathy \& Kathiresan, 2013).

Although secondary metabolites normally do not fulfill primary functions such as organism growth, there are always exceptions. Great examples are a group of phenolic compounds known as phlorotannins, which are found exclusively in algae, especially in brown algae, and participate in the development and growth of the cell walls (Liu et al., 2011). Phlorotannins can be defined as polymers of phloroglucinol units (1,3,5-tryhydroxybenzene), and are synthesized in algae through the acetate - malonate pathway (also known as polyketide pathway), originating compounds of wide ranges of molecular size (126-650 kDa) (Agregán et al., 2017; Eom, Kim, \& Kim, 2012). They are hydrophilic compounds that contain both phenolic and phenoxy groups in their structure and can be divided into four large subgroups: phlorethols and fuhalols (they have both bonds), fucols (they contain phenyl bonds), fucophloroethols (they have ether and phenyl bonds), and eckols (with dibenzodioxin bonds). Several phlorotannins have been associated with the exertion of biological properties, beneficial for the human health, such as antioxidant or antimicrobial activities (Li, Wijesekara, Kim, \& Li, 2011).

Among the properties associated with phenolic compounds present in seaweed, it is worth highlighting their antioxidant activity because their capacity of exerting a scavenging action is related to further bioactivities, such as anti-inflammatory, antitumoral, hypocholesterolemic, anticoagulant, antiviral and antimicrobial activities. For this reason, there is a growing interest in the study and development of innovative strategies to optimize the extraction of these bioactive compounds from seaweeds; aiming to use them as functional ingredients in the food industry, or to incorporate them in cosmetic formulations and pharmaceutical preparations with therapeutic purposes (Abad, 2013). Those are practical, useful and interesting challenges that are discussed on the present manuscript, which collects and compare published literature from documents regarding algae-contained phenolic compounds' extraction, classification, stability, identification and bioactivities. Databases consulted with this purpose were Scopus, Algaebase and ScienceDirect.

\section{Classification of phenolic compounds from algae}

Phenolic compounds are present in an immense variety of terrestrial and marine plants, due to their importance and contribution to organisms' growth and survival, also helping in the defense against pathogens and predators. These compounds can be synthetized following pentose phosphate, shikimate or phenylpropanoid pathways.

Regarding their chemical structure, all phenolic compounds comprise at least one aromatic phenolic ring with one or more hydroxyl substituents that can be highly polymerized, which allows their classification, with more than 8000 different structures being currently known. To carry out its classification, different criteria can be followed. One of them is based on the number of carbons in the molecule (Fig. 1). Other types of classifications are based on their level of distribution (shortly distributed, widely distributed and polymers), or according to their characteristics or properties (soluble and insoluble). From a nutritional point of view, this last classification is very useful since insoluble phenolic compounds will not cross the intestinal barrier to reach the blood. This variety of classifications occurs since phenolic compounds comprise a large number of heterogeneous structures that range from a very simple to a highly polymerized structural level (de Giada, 2016; Vermerris \& Nicholson, 2006). Some of them show bioactivities represented in Table 1.

\subsection{Simple phenolic}

This group is formed by phenols that present hydroxyl substituents in different positions: ortho, meta, and para (1,2-, 1,3- and 1,4-, respectively). Moreover, simple phenolics sometimes show three functional groups. In this case, it can be meta-tri substitution $(1,3,5-)$ or victri substitution (1,2,6-) (Vermerris \& Nicholson, 2006). Examples of compounds that belong to this group are catechol, hydroquinone, and phloroglucinol, the last one being found exclusively in macroalgae (Tsimogiannis \& Oreopoulou, 2019). A study showed that catechol was detected in 27 Japanese seaweed, which correspond to green or red algae (Yoshie-Stark \& Hsieh, 2003). It is quite common to find phenols with bromine substituents which are called bromophenols. Fig. 2 contains the chemical structures of some relevant phenolic compounds that can be found in algae.

\subsection{C6-CN phenolic compounds}

This group is formed by compounds whose basic skeleton is $\mathrm{C}_{6}-\mathrm{C}_{\mathrm{N}}$ being $\mathrm{N} 1 \leq \mathrm{N} \leq 3$. Within this group, three subdivisions can be made in $\mathrm{C}_{6}-\mathrm{C}_{1}, \mathrm{C}_{6}-\mathrm{C}_{2}$, and $\mathrm{C}_{6}-\mathrm{C}_{3}$. (Fig. 1). $\mathrm{C}_{6}-\mathrm{C}_{1}$ correspond to phenolic acids and aldehydes, which are characterized by the presence of a carboxyl group as a substitute on a phenol (Vermerris \& Nicholson, 2006). One of the most abundant simple phenolic acids belonging to this group is gallic acid, commonly used as standard in total phenolic compounds quantification. It can be found in some algae in high concentrations, as is the case of the brown alga Halopteris scoparia (Linnaeus) Sauvageau, which also contains gentisic acid. Other simple acids have been also found in algae, like 4-hydroxybenzoic acid in brown alga Undaria pinnatifida (Harvey) Suringar (Mekinić et al., 2019). Compounds belonging to the $\mathrm{C}_{6}-\mathrm{C}_{2}$ group are known as phenylethanoids and include hydroxylated and/or methoxylated derivatives of phenylacetic acid, acetophenone, and phenethyl alcohol. They are not very common in nature. 
<smiles>Oc1ccccc1</smiles>

Simple phenolics

(C6)<smiles>O=C(O)c1ccccc1</smiles>

$\mathrm{HO}$<smiles>O=C(O)c1ccc(I)cc1</smiles>

Phenolic acids, hydroxybenzoic acids (C6-C1)<smiles>CC(=O)c1ccccc1</smiles><smiles>O=C(O)Cc1ccccc1</smiles>

Acetophenones, phenylacetic acids (C6-C2)<smiles>C/C=C\c1ccccc1/C=C/C(=O)O</smiles>

Coumarins, hydroxycinnamic acids, phenylpropanoids (C6-C3)<smiles>C(=C/c1ccccc1)\c1ccccc1</smiles><smiles>O=C1c2ccccc2C(=O)c2ccccc21</smiles>

Stilbenoids, anthraquinones (C6-C2-C6)<smiles>O=C1C=CC(=O)c2ccccc21</smiles>

Naphthoquinones (C6-C4)<smiles>O=c1c2ccccc2oc2ccccc12</smiles>

Xanthones (C6-C1-C6)<smiles>c1ccc(C2CCc3ccccc3O2)cc1</smiles><smiles>c1ccc(C2COc3ccccc3C2)cc1</smiles>

Flavonoids, isoflavonoids (C6-C3-C6)<smiles>COc1cc(C2OCC3C(c4ccc(O)c(OC)c4)OCC23)ccc1O</smiles>

Lignans, neolignans ([C6-C3]2)<smiles>COc1ccc(C(=O)C(C)CO)cc1O</smiles>

Lignins ([C6-C3]n)<smiles>[R]c1cc([C@@H]2Oc3c(O)cc(O)cc3C(c3c(O)cc(O)c4c3O[C@H](c3cc([R])c(O)c(O)c3)[C@@H](O)C4)C2O)cc(O)c1O</smiles>

Condensed tannins ([C6-C3-C6]n)

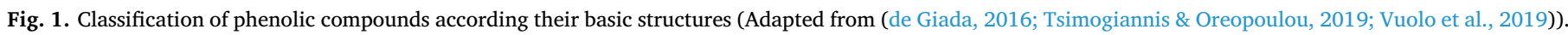

Among the $\mathrm{C}_{6}-\mathrm{C}_{3}$ category are phenylpropanoids, among which we can highlight hydroxycinnamic acids, cinnamic aldehydes, monolignols, phenyl propenes, coumarins, isocoumarins, and chromones. They can be found in the red alga Tichocarpus crinitus (S.G.Gmelin) Ruprecht (Ishii, Okino, Suzuki, \& Machiguchi, 2004; Tsimogiannis \& Oreopoulou, 2019). Among the cinnamic-like acids, it is worth highlighting p-coumaric acid, caffeic acid, ferulic acid, 5-hydroxyferulic acid, chlorogenic acid and sinapic acid. Coumarins have the same skeleton as cinnamic acids, but they have an oxygen heterocycle as part of the $\mathrm{C}_{3}$-unit. They have been found in green algae such as Dasycladus vermicularis (Scopoli) Krasser, and they can be also be found as sulfated metabolites, as in the case of 7-hydroxycoumarin-3,6-disulfate (Hartmann, Ganzera, Karsten, Skhirtladze, \& Stuppner, 2018). Regarding isocoumarins, they differ from coumarins in that the position of the carbonyl and oxygen groups

Table 1

Main bioactive compounds in marine algae. ().

Adapted from Freile-Pelegrín \& Robledo, 2013

\begin{tabular}{|c|c|c|}
\hline COMPOUNDS & ALGAL CLASS & ALGAE SPECIE \\
\hline \multirow[t]{3}{*}{ Bromophenols } & Rhodophyceae & Pterocladia capillacea, Odonthalia corymbifera, Rhodomela confervoides, Jania rubense \\
\hline & Phaeophyceae & Padina arborescens, Sargassum siliquastrum, Lobophora variegata, Meroditerpenoids Sargassum fallax \\
\hline & Chlorophyceae & Codium fragile, Avrainvillea longicaulis, Avrainvillea nigricans, Avrainvillea rawsonii \\
\hline Terpenoids & Rhodophyceae & Laurencia sp., Callophycus serratus \\
\hline \multirow[t]{2}{*}{ Mycosporine-like amino acids } & Rhodophyceae & Porphyra sp. \\
\hline & Chlorophyceae & Prasiola spp. \\
\hline Tichocarpol & Rhodophyceae & Tichocarpus crinitus \\
\hline Phlorotannins & Phaeophyceae & Eisenia bicyclis, Ecklonia cava, Ecklonia kurome, Ecklonia stolonifera, Ishige okamurae, Eisenia arborean \\
\hline Colpol & Phaeophyceae & Colpomenia sinuosaq \\
\hline Coumarins & Phaeophyceae & Dasycladus vermicularis \\
\hline Vanillic acid & Phaeophyceae & Cladophora socialis \\
\hline
\end{tabular}


<smiles>Oc1ccccc1O</smiles>

Catechol<smiles>Oc1ccc(O)cc1</smiles>

Hydroquinone<smiles>Oc1cc(O)cc(O)c1</smiles>

Phloroglucinol<smiles>O=C(O)c1cc(O)c(O)c(O)c1</smiles>

Gallic acid<smiles>O=C(O)c1cc(O)ccc1O</smiles>

Gentisic acid<smiles>O=C(O)c1ccc(O)cc1</smiles>

4-hydroxybenzoic acid<smiles>O=C(/C=C/c1ccc(O)c(O)c1)O[C@H]1C[C@](O)(C(=O)O)C[C@H](O)[C@H]1O</smiles><smiles>O=C(O)/C=C/c1ccc(O)cc1</smiles><smiles>O=C(O)/C=C/c1ccc(O)c(O)c1</smiles>

Caffeic acid<smiles>COc1cc(/C=C/C(=O)O)ccc1O</smiles>

Ferulic acid<smiles>COc1cc(/C=C/C(=O)O)cc(OC)c1O</smiles>

Sinapic acid<smiles>O=c1oc2cc(O)c(OS(=O)(=O)O)cc2cc1O</smiles>

7-hydroxycoumarin-3,6-disulfate<smiles>Oc1cc(O)c2c(c1)O[C@H](c1ccc(O)c(O)c1)[C@H](O)C2</smiles>

(+)-Catechin<smiles>Oc1cc(O)c2c(c1)OC(c1ccc(O)c(O)c1)C(O)C2</smiles>

Epicatechin<smiles>O=C(O[C@H]1Cc2c(O)cc(O)cc2O[C@@H]1c1ccc(O)c(O)c1)c1cc(O)c(O)c(O)c1</smiles><smiles>Oc1cc(O)cc(Oc2c(O)cc(O)c3c2Oc2c(O)cc(O)cc2O3)c1</smiles>

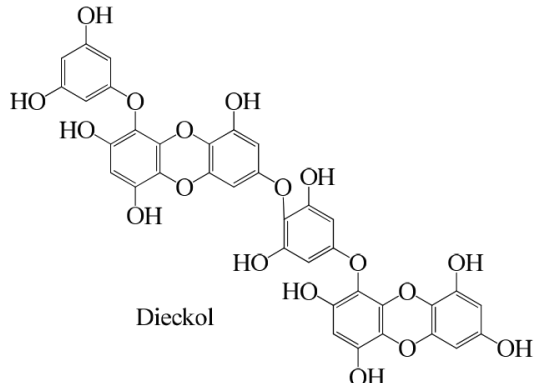<smiles>CCOCCN(CC)CCO</smiles>

Fig. 2. Representative chemical structures of phenolic compounds found in marine algae.

are reversed (Freile-Pelegrín \& Robledo, 2013; Vermerris \& Nicholson, 2006).

\subsection{C6-CN-C6 phenolic compounds}

Within this group, four subdivisions can be made: $\mathrm{C}_{6}-\mathrm{C}_{1}-\mathrm{C}_{6}$ category (xanthonoids), $\mathrm{C}_{6}-\mathrm{C}_{2}-\mathrm{C}_{6}$ category (stilbenoids, anthraquinones, and anthrones), $\mathrm{C}_{6}-\mathrm{C}_{3}-\mathrm{C}_{6}$ category (flavonoids) and $\mathrm{C}_{6}-\mathrm{C}_{7}-\mathrm{C}_{6}$ (diarylheptanoids). $\mathrm{C}_{6}-\mathrm{C}_{3}-\mathrm{C}_{6}$ category can be divided into three groups depending on the arrangement of the $\mathrm{C}_{3}$ group that links the two benzene rings. They are chalcones (linear $\mathrm{C}_{3}$-chain), aurones (cyclization of chalcones), and flavonoids (six-member heterocycle) (Vermerris \& 
Nicholson, 2006). In a deeper structural classification, flavonoids can be further divided into 13 classes, being the most important ones flavanols, flavones, isoflavones, anthocyanins, and flavanones (de Giada, 2016). A study concerning 27 species of Japanese red algae showed that hesperidin was found in all of them, being Caulerpa serrulata (Forsskål) J.Agardh the one that showed the major concentration. Said study concluded that in general, red algae have a higher content in flavonoids than green and brown algae (Yoshie-Stark \& Hsieh, 2003). Other recognized, well-known and abundant flavonoids found in algae, belonging to flavan-3-ols subgroup, are catechin and epicatechin, catechin gallate and epigallocatechin. They are widely present in brown algae species, such as Eisenia bicyclis (Kjellman) Setchell, Sargassum fusiforme (Harvey) Setchell and Saccharina japonica (Areschoug) C.E.Lane (Mekinić et al., 2019).

\subsection{Lignans}

This type of phenolic compounds is a dimer or oligomer that is formed due to the union of monolignols - p-coumaryl alcohol, coniferyl alcohol, and sinapyl alcohol (Vermerris \& Nicholson, 2006). Although it was thought it would only be present in terrestrial plants, it has also been discovered in calcified intertidal red seaweed Calliarthron cheilosporioides Manza (Freile-Pelegrín \& Robledo, 2013).

\subsection{Lignins}

Among polymeric phenols, it is worth mentioning tannins and lignins. These last ones are the most abundant organic polymers in nature, in which their structure is composed of complicated monolignol (coumaryl, coniferyl, and sinapyl alcohol) and lignan (dimers of monolignols) units, nonlinearly and randomly linked forming a polymer with a three-dimensional network. However, they haven't been extensively studied in marine organisms, such as algae (Tsimogiannis \& Oreopoulou, 2019).

\subsection{Tannins}

Tannins are usually divided into three chemically groups based on their structures: hydrolysable tannins (or pyrogallol-type tannins), flavonoid-based condensed tannins (or polyflavonoid tannins, catecholtype tannins, pyrocatechollic type tannins, nonhydrolyzable tannins, or flavolans) and phlorotannins. Hydrolysable tannins are derived from simple phenolic acids and their carbohydrates' hydroxyl groups are partially or completely esterified with phenolic groups. Flavonoidbased condensed tannins are formed through biosynthesis of flavins and catechins, being scarce the information on the content of flavonoids in algae. Phlorotannins are oligomers of phloroglucinol that are exclusively found in marine algae, especially in brown algae. Phlorotannins represent the most studied group of phenolic compounds obtained from algae, since it can come to represent up to $25 \%$ of the alga dry weight (Freile-Pelegrín \& Robledo, 2013). Some remarkable examples of these particular tannins contained just in algae are triphloroethol-A, eckol, dieckol, and eckstolonol (Mekinić et al., 2019).

\subsection{Phenolic terpenoids}

This type of compounds have been found in brown (meroditerpenoids: plastoquinones, chromanols, chromenes) and red macroalgae (diterpenes and sesquiterpenes), more common in Sargassaceae and Rhodomelaceae (Freile-Pelegrín \& Robledo, 2013).

\subsection{Mycosporine-like amino acids (MAAs)}

MAAs have been discovered in many different marine and freshwater species including cyanobacteria, fungi, algae (cyanobacteria, Rhodophyta, and some microalgae, among others) and animals. In the case of marine algae, these compounds are generally found free in the intracellular space and concentrated around organelles sensitive to UV rays. As for its molecular structure, they are formed by cyclohexenone or cycloheximide chromophore conjugated to an amino acid residue or its imino alcohol (Carreto \& Carignan, 2011; Freile-Pelegrín \& Robledo, 2013; Rosic, Braun, \& Kvaskoff, 2015).

\section{Extraction technologies for phenolic compounds}

Although there are several extraction methodologies for obtaining phenolic compounds, two general types of extraction techniques are found: conventional extraction techniques and non-conventional extraction techniques. The traditional techniques refer to simple solidsolvent extractions, and the non-conventional ones include pressurized liquid extraction, microwave-assisted extraction, ultrasound-assisted extraction and subcritical $\mathrm{CO}_{2}$ extraction, among others.

\subsection{Traditional techniques}

Traditional extractions usually include maceration, also known as heat assisted extraction, percolation, and Soxhlet extraction (Aires, 2017). The use of this kind of extractions is a current practice, widely employed around the world. The most common extractive solvents applied are methanol, ethanol, acetone, water, and ethyl ethanoate in different combinations, and they are selected based on the polarity of the molecules to extract. Phenolic compounds mostly tend to hydrophilicity, so solvents such as hydroalcoholic mixtures are very effective for this process. Some authors have demonstrated that using a combination of solvent with acids, such as citric acid, tartaric acid, or hydrochloric acid could improve the extraction efficiency of those compounds (Santos-Buelga, Gonzalez-Manzano, Dueñas, \& GonzalezParamas, 2012; Vieira et al., 2018).

Within the traditional extractions techniques, it is worth mentioning that the Soxhlet extraction gets better results in terms of yield, although this technique also presents some disadvantages such as the degradation of thermolabile compounds (as anthocyanins, hydrolysable tannins or some phenolic acids) or the requirement of relatively large amounts of solvents and the long times of processing. Normally, the Soxhlet technique is used for the extraction of lipophilic compounds (SantosBuelga et al., 2012).

Regarding heat-assisted extraction, it can be divided into two steps. The first one is the faster step and consists of a compounds transference from the matrix surface to the solvent. The second one is slower, thus consists of diffusion from the inside part of the matrix to the solvent. Critical and determining parameters in this process are the type of sample and solvent selected, and the temperature and time of the extraction, so many kinds of approaches can be done using this technique, according to the large amplitude of the variables involved. The main disadvantage is that it is needed a filtration, clarification or decantation to separate the solid parts when the extraction is finished. Besides, it usually requires large number of solvents and longs times, a characteristic also shared by percolation, a method consisting in a container where the powder sample is placed, and through which the extractive solvent is discharged drop by drop from one extreme to another by gravity (Aires, 2017).

\subsection{Innovative techniques}

\subsubsection{Pressurized liquid extraction (PLE)}

This type of extraction, also known as extraction with pressurized solvent (PSE), is characterized by using high pressures (10 to $15 \mathrm{MPa}$ ), short processing times and temperature ranges that can comprise between 50 and $200{ }^{\circ} \mathrm{C}$, all using low volumes of non-toxic solvents in the extraction, and thus being considered a green technology (Table 2 part A). The application of four different solvents (hexane, ethyl acetate, pure ethanol and $50 \%$ ethanol) for the extraction of phenolic 
Table 2

Different experimental conditions used for the extraction of bioactive compounds from marine algae.

\begin{tabular}{|c|c|c|}
\hline ALGAE SPECIE & EXTRACTION CONDITIONS \& YIELDS & REFERENCES \\
\hline \multicolumn{3}{|l|}{ A) Pressurized Liquid Extraction (PLE) } \\
\hline L. ochroleuca & $1 \mathrm{~g}$ algae dw; 1450 bar; $80-160{ }^{\circ} \mathrm{C} ; 37-52 \%$ yield. & (Otero et al., 2019) \\
\hline S. muticum & $\begin{array}{l}2 \mathrm{~g} \text { of algae dw; } 1500 \mathrm{bar} ; 120^{\circ} \mathrm{C} \text {; ethanol:water }(75: 25, \mathrm{v} / \mathrm{v}) ; 20 \mathrm{~min} ; 40 \% \\
\text { yield. }\end{array}$ & (Sánchez-Camargo et al., 2016) \\
\hline Phaeophyta species from Brittany coasts & $10 \mathrm{~g}$ algae dw; 1500 bar; $75^{\circ} \mathrm{C}$; dichloromethane:methanol (1:1, v/v). & (Zubia, Fabre, \& Shannon, 2009) \\
\hline A. nodosum, $P$. canaliculata, $F$. spiralis \& $U$. intestinalis & $\begin{array}{l}2.5 \mathrm{~g} \text { algae dw; } 1500 \mathrm{bar} ; 120{ }^{\circ} \mathrm{C} \text {; acetone:water }(80: 20, \mathrm{v} / \mathrm{v}) ; 60 \mathrm{~min} ; \approx \\
20 \% \text { yield. }\end{array}$ & (Tierney et al., 2013) \\
\hline $\begin{array}{l}\text { C. vulgaris, } S . \text { vulgare, Porphyra spp., C. abies-marina, } S \text {. } \\
\text { muticum, U. pinnatifida \& H. incurvus }\end{array}$ & $1 \mathrm{~g}$ algae dw; 1500 bar; $100 / 200{ }^{\circ} \mathrm{C} ; 5 \mathrm{~min} ; 12-68 \%$ yield & $\begin{array}{l}\text { (Plaza, Amigo-Benavent, del Castillo, } \\
\text { Ibáñez, \& Herrero, 2010) }\end{array}$ \\
\hline \multicolumn{3}{|l|}{ B) Microwave Assisted Extraction (MAE) } \\
\hline S. vestitum & $0.5 \mathrm{~g}$ algae dw; $960 \mathrm{~W} ; 1.25 \mathrm{~min}$; ethanol 70\%; 6\% yield & (Dang et al., 2018) \\
\hline A. nodosum, L.japonica, L. trabeculate \& L. nigrecens & $30 \mathrm{~g}$ algae dw; $110{ }^{\circ} \mathrm{C} ; 2450 \mathrm{MHz} ; 15 \mathrm{~min}$; methanol 70\%; 5-20\% yield. & (Yuan et al., 2018) \\
\hline C. racemosa & $4 \mathrm{~g}$ algae dw; $50{ }^{\circ} \mathrm{C} ; 200 \mathrm{~W} ; 40 \mathrm{~min}$; ethanol:water $60 \% ; 7 \%$ yield. & (Li et al., 2012) \\
\hline E. prolifera & $5 \mathrm{~g}$ algae dw; $500 \mathrm{~W} ; 25 \mathrm{~min}$; ethanol:water $30 \%$; $10 \%$ yield. & $\begin{array}{l}\text { (HongYu, Bin, ChunGuang, \& YinFeng, } \\
\text { 2010) }\end{array}$ \\
\hline \multicolumn{3}{|l|}{ C) Ultrasound Assisted Extraction (UAE) } \\
\hline H. banksii & $1 \mathrm{~g}$ algae dw; $50 \mathrm{KHz} ; 150 \mathrm{~W} ; 50 \mathrm{~mL}$; ethanol 70\%; $30{ }^{\circ} \mathrm{C} ; 60 \mathrm{~min}$. & (Dang et al., 2017) \\
\hline L. obtuse & $1 \mathrm{~g}$ algae dw; $40 \mathrm{KHz} ; 250 \mathrm{~W} ; 30 \mathrm{~mL}$; ethanol 95\%; $50^{\circ} \mathrm{C} ; 45 \mathrm{~min}$. & $\begin{array}{l}\text { (Topuz, Gokoglu, Yerlikaya, Ucak, \& } \\
\text { Gumus, 2015) }\end{array}$ \\
\hline A. nodosum \& L. hyperborea & $\begin{array}{l}\text { 4-10 g algae dw; } 20 \mathrm{KHz} ; 750 \mathrm{~W} ; 40-200 \mathrm{~mL} \text {; distilled water ( } 0.03 \mathrm{M} \mathrm{HCl}) \text {; } \\
10-15 \text { min. }\end{array}$ & $\begin{array}{l}\text { (Kadam et al., 2015a; Kadam, Tiwari, } \\
\text { Smyth, \& O’Donnell, 2015) }\end{array}$ \\
\hline E. cava & $\begin{array}{l}1 \mathrm{~g} \text { algae dw; } 40 \mathrm{KHz} ; 200 \mathrm{~W} ; 100 \mathrm{~mL} \text {; different solvents (water } 100 \% \text {, } \\
\text { methanol } 50 \% \text {, methanol } 100 \% ; 30{ }^{\circ} \mathrm{C} ; 6-15 \mathrm{~min} .\end{array}$ & (Lee \& Kim, 2015) \\
\hline S. muticum, O. pinnatifida \& C. tomentosum & $2 \mathrm{~g}$ algae dw; $60 \mathrm{KHz} ; 400 \mathrm{~W} ; 50 \mathrm{~mL}$; deionized water; $50{ }^{\circ} \mathrm{C} ; 60 \mathrm{~min}$. & (Rodrigues et al., 2015) \\
\hline L. japonica & $1 \mathrm{~g}$ algae dw; $20 \mathrm{KHz} ; 200 \mathrm{~W} ; 15 \mathrm{~mL}$; ionic liquid [BMIM][BF4]; $60 \mathrm{~min}$. & (Han, Zhu, \& Row, 2011) \\
\hline \multicolumn{3}{|l|}{ D) Subcritical Water Extraction (SWE) } \\
\hline S. muticum & $2 \mathrm{~g}$ algae dw; $1500 \mathrm{psi} ; 50-200{ }^{\circ} \mathrm{C} ; 20 \mathrm{~min}$. & (del Sánchez-Camargo, 2017) \\
\hline S. platensis & $2.5 \mathrm{~g}$ algae $\mathrm{dw} ; 1500 \mathrm{psi} ; 115-170 ; 9-15 \mathrm{~min}$. & $\begin{array}{l}\text { (Herrero, Martín-Álvarez, Señoráns, } \\
\text { Cifuentes, \& Ibáñez, 2005) }\end{array}$ \\
\hline F. serratus, $L$. digitata, G. gracilis \& C. fragile & $2.5 \mathrm{~g}$ algae dw; $1500 \mathrm{psi} ; 120^{\circ} \mathrm{C} ; 25 \mathrm{~min}$. & (Heffernan et al., 2014) \\
\hline $\begin{array}{l}\text { C. abies-marina, Porphyra spp., S. vulgare, S. muticum, } \\
\text { U. pinnatifida \& H. incurvus }\end{array}$ & $1 \mathrm{~g}$ algae dw; $1500 \mathrm{psi} ; 120-200{ }^{\circ} \mathrm{C} ; 20 \mathrm{~min}$. & (Plaza et al., 2010) \\
\hline \multicolumn{3}{|l|}{ E) Supercritical $\mathrm{CO}_{2}$ Extraction ( $\mathrm{SC}-\mathrm{CO}_{2}$ ) } \\
\hline U. pinnatifida & $10 \mathrm{~g}$ algae dw; $250 \mathrm{bar} ; 60^{\circ} \mathrm{C} ; 0.12 \mathrm{~L} / \mathrm{h} ; 0.83 \mathrm{~h}$; yield of $780 \mathrm{mg} / \mathrm{g}$. & (Roh, Uddin, \& Chun, 2008) \\
\hline P. valderianum & $10 \mathrm{~g}$ algae dw; 500 bar; $50{ }^{\circ} \mathrm{C} ; 120 \mathrm{~L} / \mathrm{h} ; 1.5 \mathrm{~h}$; yield of $3.97 \mathrm{mg} / \mathrm{g}$. & (Chatterjee \& Bhattacharjee, 2014) \\
\hline C. glomerata, U. flexuosa \& C. fragilis & $10 \mathrm{~g}$ algae dw; $300 \mathrm{bar} ; 40{ }^{\circ} \mathrm{C} ; 300 \mathrm{~L} / \mathrm{h} ; 2 \mathrm{~h}$; yield of $30.20 \mathrm{mg} / \mathrm{g}$. & $\begin{array}{l}\text { (Fabrowska, Ibañez, Łęska, \& Herrero, } \\
\text { 2016) }\end{array}$ \\
\hline
\end{tabular}

compounds from the brown alga Laminaria ochroleuca Bachelot Pylaie at 100 bar was tested, observing that the highest extraction yield $(37 \%$ for $80{ }^{\circ} \mathrm{C}$ and $52 \%$ for $160{ }^{\circ} \mathrm{C}$ ) was obtained using ethanol diluted in water (Otero, López-Martínez, \& García-Risco, 2019).

Several studies showed the advantages of this extractive method when carried out in the absence of light and oxygen, because it favors the conservation of compounds of interest, such as phenolic compounds (Tierney et al., 2013).

\subsubsection{Microwave-assisted extraction (MAE)}

The foundation of this method consists of the use of microwave potency that causes changes in cell structures due to electromagnetic waves. This electromagnetic energy is transformed into calorific energy by two mechanisms: ionic conduction and dipole rotation (Kalil, Moraes, Sala, \& Burkert, 2017). This technique can be performed in open (operate at atmospheric pressure) or closed vessels (pressure higher than atmospheric), and it is mainly used for the extraction of polyphenols and polysaccharides (Ciko, Jokić, Šubarić, \& Jerković, 2018).

Fundamental parameters that must be taken into account for the optimization of this type of extraction are power and frequency of microwaves, solid-to-solvent ratio, temperature, pressure, and time (Table 2 part B) (Pinela et al., 2016). It is important to notice that high microwave power and elevated temperatures may destroy phenolic compounds. Regarding extraction solvents, these compounds are easily dissolved when using hydroalcoholic mixtures with intermediate ethanol concentrations (Ciko et al., 2018).

The application of this extraction technique to obtain phenolic compounds from brown algae showed good results (Yuan et al., 2018). A study regarding the optimization of the extraction of phenolic compounds from brown alga Sargassum vestitum (R.Brown ex Turner) C.Agardh was carried out to maximize the extraction yields. The conclusion was that the most important variable affecting this methodology is solvent nature and concentration, followed by radiation time and power (Dang, Bowyer, Van Altena, \& Scarlett, 2018).

\subsubsection{Ultrasound-assisted extraction (UAE)}

This method uses ultrasound waves with a frequency between $20 \mathrm{kHz}$ and $100 \mathrm{kHz}$ which originate bubbles due to the pressure difference that is created. Then these bubbles collapse and cavitation occur, causing near liquid-solid interfaces breakdown of particles with the consequent release of bioactive compounds to the matrix. The main advantages of the application of UAE on the phenolic compounds extraction from algae include low temperatures, short times and low amount of solvent (Ciko et al., 2018). However, it must be noticed that ultrasonication time can increase temperature, what can compromise phenolic compounds' stability. The parameters to optimize in this kind of extractions are frequency, power, temperature, time, and solid:solvent ratio (Heleno et al., 2016) (Table 2 part C).

\subsubsection{Subcritical water extraction (SWE)}

This method consists of applying water at higher temperatures than its boiling point $\left(100-374{ }^{\circ} \mathrm{C}\right)$ under high pressure (10-60 bar) to maintain its liquid state for a short time (5-10 min). One of the most important factors to take into account in this type of extraction is the variability of the dielectric constant with temperature (Herrero, 
Cifuentes, \& Ibañez, 2006). Main parameters that should be taken into account and that can be optimized when using this methodology are pressure, time, and temperature, as well as selecting an appropriate solvent (Zakaria \& Kamal, 2016) (Table 2 part D).

\subsubsection{Supercritical $\mathrm{CO}_{2}$ extraction $\left(\mathrm{SC}-\mathrm{CO}_{2}\right)$}

This method allows multiple combinations of temperature and pressure. Besides, $\mathrm{CO}_{2}$, which is a non-toxic gas, is used as a supercritical fluid so fluid behaves like liquid and gas simultaneously which makes extraction easier. The polarity of $\mathrm{CO}_{2}$ can be modified by the use of co-solvents such as ethanol, and in this way also extract polar components. As low temperatures and pressure are used, the thermal degradation of phytochemicals is prevented (Aires, 2017) (Table 2 part E).

\section{Stability of phenolic compounds}

Phenolic compounds possess high stability when they are in the original fresh matrix and are well preserved at low temperatures, but, when extracted, it is important to take certain precautions to avoid degradation. In the case of using algae as raw material to obtain phenolic compounds, it is advisable to carry out the extraction as quickly as possible once the raw material has been acquired. If this is not possible, the conservation of the matrix is more effective after the application of any of the following methodologies: freezing, freeze-drying or drying in a steam room. The most common technique used to this purpose is drying in the air at room temperature, since drying at high temperatures normally leads to loss of volatile compounds and unnecessary degradation of phenolic compounds (Wong \& Chikeung Cheung, 2001).

Phenolic compounds present in algae are especially sensitive to heat and light, particularly UV radiation (López, Caleja, Prieto, Sokovic, Calhelha, Barros, \& Ferreira, 2019). These factors may lead to reductions in the biological properties of the compounds, due to their decomposition, as was shown in a study in which two algae extracts from Sargassum muticum (Yendo) Fensholt and Bifurcaria bifurcata R.Ross were submitted to different processes to compare their effects: drying in oven at $\sim 55{ }^{\circ} \mathrm{C}$ for $4 \mathrm{~h}$, and greenhouse drying exposed to light, at $\sim 23{ }^{\circ} \mathrm{C}$ for $72 \mathrm{~h}$, resulting in both methods producing significant reductions (Agregán et al., 2017; Le Lann, Jégou, \& Stiger-Pouvreau, 2008; Lim \& Murtijaya, 2007). In general, all drying processes that involve temperatures above $40{ }^{\circ} \mathrm{C}$ are associated with losses of phenolic compounds (Lim \& Murtijaya, 2007; Wong \& Chikeung Cheung, 2001), although there are always exceptions, such as some polyphenols, which did not suffer apparent degradation during a drying process carried out at $60{ }^{\circ} \mathrm{C}$ (Larrauri, Rupérez, \& Saura-Calixto, 1997). Some authors state that there are three possible mechanisms responsible for the degradation of these compounds at high temperatures:

(i) the breaking of bonds between phenolic compounds and cell walls;

(ii) partial degradation of cell walls polymers due to oxidative changes in the structures of aromatic compounds and;

(iii) thermal degradation of the polyphenols themselves caused by oxidative enzymes (e.g. peroxidases), whose deactivation does not occur immediately (Maillard \& Berset, 1995).

Another possible cause of degradation of some phenolic compounds is a direct exposure to sunlight, hence greenhouse drying is also not a good idea. In fact, in the extractions carried out in the dark, greater amounts of total phenolic compounds with potent antioxidant activity values were obtained (Le Lann et al., 2008). The use of the drying technique was able to avoid the loss of heat-sensitive products, however, there were changes in the native conformation of certain molecules that could lead to a reduction in bioactive capacities (Franks, 1998). Therefore, the best option is the extraction of phenolic compounds directly from fresh algae, at low temperatures, and in the absence of light, although, if this is not possible, extraction from frozen and/or freeze-dried matrices is recommended (Le Lann et al., 2008).

\section{Robust identification of phenolic compounds}

Phenols have been detected in samples using very varied techniques, such as spectrometric, biological, or analytical ones. Spectrometric assays are usually employed as a screening tool which allows estimating the antioxidant capacity of the samples which is mostly related to the total content of phenolic compounds. These in vitro methods can be classified into two groups, based on the transfer reaction of a single electron or a hydrogen atom (Vuolo, Lima, \& Maróstica Junior, 2019). The first group includes methods such as Trolox equivalent antioxidant capacity (ABTS or TEAC) assay, the ferric reducing ability of plasma (FRAP) assay, the 2,2-diphenyl-1-picrylhydrazyl (DPPH) radical scavenging capacity assay or the $\beta$-carotene test (Rojas \& Buitrago, 2019; Vuolo et al., 2019). During the redox reaction, colorimetric changes are observed, correlated with the concentration of antioxidant species present in the sample (Vuolo et al., 2019). On the other group, some examples are the oxygen radical absorbance capacity (ORAC) assay, peroxyl scavenging capacity (PSC), or the total peroxyl radical-trapping antioxidant parameter (TRAP) assay. Substrates and antioxidant molecules compete to join peroxyl radical and this reaction is monitored and evaluated (Vuolo et al., 2019). Another important assay to analyze the effect of phenols is that based on the use of in vivo models, mainly performed on mice and rats, but also guinea-pigs, rabbits and fish (Martins, Barros, \& Ferreira, 2016; Rojas \& Buitrago, 2019; Vuolo et al., 2019). The antioxidant activity of phenolic compounds is evaluated by the effect displayed on parameters associated with the redox homeostasis, such as catalase, superoxide dismutase, glutathione peroxidase, malondialdehyde, peroxidase, ferric reducing antioxidant power, heme oxygenase-1, and many other factors (Martins et al., 2016; Vuolo et al., 2019). These two categories of assays, especially the spectrometric ones, are widely applied in the field of phenols but they only permit to estimate and evaluate the number of phenols in a sample. To identify and quantify the chemical profile of phenolic compounds analytical methods must be used. This method allows the study of many different molecules in just one experiment; however, this throughput is subject to the chromatographic separation of the component of the samples. High-performance liquid chromatography (HPLC) is the most common technique applied for the field of phenols although other techniques such as gas chromatography (GC) have been used. Regarding identification, many detectors have been coupled to HPLC such as the ultraviolet (UV) or photodioarray detectors (PDA). Nevertheless, the most relevant instruments to identify or determine molecular structures are the HPLC or GC coupled to mass spectrometry (MS) or nuclear magnetic resonance (NMR). Therefore, since analytical methods are the only identification tool, different examples employed to identify phenolic compounds from algae are described below.

The phenolic content of five microalgae (Chaetoceros calcitrans (Paulsen) H.Takano, Isochrysis galbana Parke, Skeletonema costatum (Greville) Cleve, Odontella sinensis (Greville) Grunow, and Phaeodactylum tricornutum Bohlin) and one brown macroalga, S. japonica, C.Mayes, Druehl \& G.W.Saunders, were evaluated using HPLC coupled to a UV detector. Gallic acid was the most abundant phenolic compound, among all 10 analyzed. I. galbana showed the maximum content of gallic acid with a value of $13.6 \mathrm{mg} / \mathrm{g}$ of dry weight (DW). Other phenols, including rosmarinic, syringic, or chlorogenic acids, were found in lower concentrations with variable ranges of concentration $0.1-7.2,0.9-2.2$, and $0.1-2.0 \mathrm{mg} / \mathrm{g}$ of DW, respectively (Foo et al., 2017).

Similar phenolic compounds were observed in the study of (Klejdus et al., 2017), where rapid resolution liquid chromatography-tandem MS was used to determine the phenolic compounds present in three brown algae, Cystoseira abies-marina (S.G.Gmelin) C.Agardh, U. pinnatifida, and $S$. muticum, and in the red algae Chondrus crispus Stackhouse. Results showed that p-hydroxybenzoic acid, gallic acid, p-hydroxybenzaldehyde, vanillic acid, 3,4-dihydroxybenzaldehyde, and protocatechuic acid were the phenolic compounds found in higher 
concentration in these algae, while ferulic, p-coumaric, caffeic, syringic, and chlorogenic acid were found in a lower concentration. (Onofrejová et al., 2010) studied the phenolic compounds present in the brown alga U. pinnatifida and the red alga Porphyra tenera Kjellman using HPLCelectrospray (ESI)-MS. P. tenera showed a higher content in phenolic compounds than $U$. pinnatifida. For the first alga, p-hydroxybenzoic and salicylic acids were compounds most abundant, with values of 690 and $530 \mathrm{ng} / \mathrm{g}$, respectively. For the second one, salicylic p-hydroxybenzoic acid was also the most relevant phenols, found in concentrations of 226 and $211 \mathrm{ng} / \mathrm{g}$, respectively.

Among phenolic compounds, phlorotannins, present in brown algae, have been quite studied. For example, phenolic compounds of four brown algae (Ascophyllum nodosum (Linnaeus) Le Jolis, S. japonica, Lessonia trabeculata Villouta \& Santelices, and Lessonia nigrescens Bory) were evaluated by LC-DAD-ESI-MS/MS (Yuan et al., 2018). Several peaks were tentatively identified as phenolic acid derivatives, gallocatechin derivatives and phlorotannins. Phlorotannins present in Fucus serratus Linnaeus were studied using an HPLC coupled to a quadrupole time-of-flight (qTOF)-MS. Molecules with different polymerization degrees, between and 6 and 23 phloroglucinol units (PGUs), were found to be the major one containing 8 to 13 PGUs (Heffernan, Smyth, Fitzgerald, Soler-Vila, \& Brunton, 2014). In another study, Ecklonia stolonifera Okamura extracts were analyzed with a validated HPLC-ESIMS method. The major phlorotannins found were dieckol, eckol, and phlorofucofuroeckol-A, being the first one the most abundant (Goo, Choi, \& Na, 2010).

Several studies have employed NMR to identify phenolic compounds extracted from algae, especially phlorotannins. Phlorotannins present in the brown algae $F$. vesiculosus Linnaeus were evaluated by HPLC-UV-PDA based on the presence of the representative monomer unit of this family of compounds, the phloroglucinol. Further analyses performed by NMR confirm that this alga contains phlorotannin molecules (Koivikko, Loponen, Pihlaja, \& Jormalainen, 2007). NMR was also used to study the phlorotannins profile of the brown algae S. muticum. Extracts purified using solid-phase extraction (SPE) were analyzed. NMR-data showed a high content of a phlorotannin type known as phlorethol that comprises different units of phloroglucinol linked through aryl-ether bonds. Although, phlorethol was the main component differences in the composition and quantification of phlorethol were found depending on the geographical distribution of the algae (Tanniou et al., 2014). Similarly, the technique NMR allowed identifying and quantifying the variations of phloroglucinol content in the brown algae Cystoseira tamariscifolia (Hudson) Papenfuss throughout the year (Jégou, Kervarec, Cérantola, Bihannic, \& Stiger-Pouvreau, 2015).

\section{Mechanisms of action for the bioactivity of phenolic compounds}

Phenolic compounds have been reported to have different properties of interest for diverse applications. These molecules exert a broad range of promising health benefits, being their antioxidant, antimicrobial, anti-inflammatory and cytotoxic effects some of the bioactivities more studied (Ganzera \& Sturm, 2018; Martins et al., 2016; Vuolo et al., 2019). Besides, several other bioactivities have been associated with them, such as neuroprotective, immunomodulatory, cardioprotective, or diuretic (Ferreira, Martins, \& Barros, 2017; Vuolo et al., 2019). Thus, phenolic compounds are used in cosmetics, drugs, and also in the food industry, to enhance food quality and nutritional benefits and preserve foods (Kumar \& Goel, 2019; Martins et al., 2016).

\subsection{Antioxidant properties}

Phenolic compounds have been known to be potent antioxidants, preventing oxidative damage of nucleic acids, proteins, and other biomolecules (Ferreira et al., 2017; Vuolo et al., 2019). Their action mechanism is mainly through scavenging of free radicals, inhibition of lipid peroxidation, and also activating the endogenous antioxidant system (Ferreira et al., 2017; Kumar \& Goel, 2019; Vuolo et al., 2019). This antioxidant potential of phenolic compounds is strongly related to its structure and many factors are known to affect it, such as the hydroxyl groups, the glycosylation pattern, or the substituents. Firstly, the hydroxyl group $(-\mathrm{OH})$ are the donors of hydrogens and electrons, so its number and position influence directly the antioxidant ability of phenolic compounds. The presence of substituents on the aromatic ring affects the stabilization of the molecule and consequently the radicalscavenge activity (Kumar \& Goel, 2019; Vuolo et al., 2019). The glycosylation of the compounds has been reported to affect the antioxidant activity, as it interferes with structure, methylation, and the electron displacement of the molecule (Kumar \& Goel, 2019; Vuolo et al., 2019). Finally, methylation has been shown to reduce antioxidant ability (Vuolo et al., 2019).

Numerous studies have demonstrated the antioxidant properties of algae extracts rich in phenolic compounds. For example, a previously cited study evaluated the antioxidant properties of five microalgae and one macroalgae species. Two of the microalgae, C. calcitrans and I. galbana were demonstrated to be the most relevant ones since their antioxidant activity was the strongest. Results also showed a clear correlation between the phenolic content, especially gallic acid, and the antioxidant capacity of the microalgae and macroalgae extracts tested although carotenoids were also involved in this response (Foo et al., 2017). Similar results were observed for U. pinnafitida and P. tenera extracts that demonstrated antioxidant activity determined by TEAC assays and attributed to the different phenolic compounds identified in the samples, such as p-Hydroxybenzoic, salicylic, cinnamic and caffeic acid (Onofrejová et al., 2010). These results were. Antioxidant properties of brown macroalgae A. nodosum, S. japonica, L. trabeculata, and $L$. nigrescens were studied and significant statistical correlation between the results of antioxidant and the phenolic content of this algae was demonstrated (Yuan et al., 2018).

Green and red algae have been described to contain lower concentrations of phenolic compounds than brown algae, therefore this last group has been further studied which showed the group of the phlorotannins as the most relevant in these algae. Numerous studies have demonstrated the antioxidant effects of phlorotannins in diverse cell lines. For example, the antioxidant properties of extracts obtained from S. muticum were evaluated on Vero cells and $\mathrm{HaCaT}$ cells previously submitted to different pro-oxidant compounds: AAPH (2,2'-azobis-2methyl-propanimidamide) and $\mathrm{H}_{2} \mathrm{O}_{2}$ for the first cell line and UV-B for the second one. After the treatment with the extract rich in phenols, the production of ROS decreased in both cell lines showing that $S$. muticum extracts revert the oxidation effects (Yu et al., 2019). Similarly, E. cava extract demonstrated to be rich in diverse phlorotannins, such as eckol and dieckol) showed antioxidant effects on macrophage cells but also on zebrafish embryos, reducing the production of reactive oxygen species (ROS) (Kim et al., 2014). The antioxidant effect of extracts from the same algae species, E. cava, determined to contain high amounts of dieckol, was investigated as the defense system in obese mice. Dietary supplementation with these extracts showed an increase of catalase and glutathione peroxidases in the liver, reducing the damage caused by a high-fat diet.

\subsection{Cytotoxic properties}

In the last decades, phenolic compounds present in different marine algae species have been identified to possess antitumor and cytotoxic capabilities (Guedes, da Silva, Aguiar, de Barros, \& Pinotti, 2013). The potent antioxidant activity of polyphenols has pointed them as very promising potential anticancer agents. Phlorotannins are the main phenolic molecules present and isolated from algae, specifically from brown algae. The molecular structure of phlorotannins contains many hydroxyl groups that have been described as responsible for their 
Table 3

Antitumor, anti-inflammatory and antimicrobial activities of phenolic compounds isolated from marine algae.

\begin{tabular}{|c|c|c|c|}
\hline ALGAE SPECIE & TESTED EXTRACTS & ACTIVITIES & REFERENCES \\
\hline \multicolumn{4}{|l|}{ A) Antitumor activities } \\
\hline E. cava & Ethyl-acetate extract ( $30 \%$ polyphenols) & Inhibited migration and invasion of A549 cells & $\begin{array}{l}\text { (Lee, Kang, Jung, Kim, \& } \\
\text { Kim, 2011) }\end{array}$ \\
\hline A. esculenta & Crude polyphenols extract & Reduced viability of Caco- 2 cells & (Nwosu et al., 2011) \\
\hline A. nodosum & Crude extract ( $0.5 \%$ polyphenols) & Showed antiproliferative effects & (O’Sullivan et al., 2011) \\
\hline L. nana & Bromophenols & Reduced tumour growth & $\begin{array}{l}\text { (Shi, Li, Guo, Su, \& Fan, } \\
\text { 2009) }\end{array}$ \\
\hline E. cava & Crude extract ( $60 \%$ polyphenols) & Inhibited MMP-2 and MMP-9 activity & (Kim et al., 2006) \\
\hline U. lactuca & Polyphenols extract & Reduced viability of Caco- 2 cells & (Nwosu et al., 2011) \\
\hline O. colensoi & Bromophenols & $\begin{array}{l}\text { Showed moderate cytotoxic activity against leukaemia } \\
\text { cells }\end{array}$ & $\begin{array}{l}\text { (Popplewell \& } \\
\text { Northcote, 2009) }\end{array}$ \\
\hline P. palmata & Polyphenols extract & Reduced viability of Caco-2 cells & (Nwosu et al., 2011) \\
\hline \multicolumn{4}{|l|}{ B) Anti-inflammatory activities } \\
\hline E. bicyclis & $\begin{array}{l}\text { Phloroglucinol, eckol, phlorofucofuroeckol A \& } \\
\text { dioxinodehydroeckol }\end{array}$ & $\begin{array}{l}\text { Inhibition of LPS-induced nitric oxide (NO) production in } \\
\text { RAW } 264.7 \text { cells }\end{array}$ & $\begin{array}{l}\text { (Jung, Jin, Ahn, Lee, \& } \\
\text { Choi, 2013) }\end{array}$ \\
\hline E. arborea & Phlorofucofuroeckol B & Inhibitory effects on histamine release & (Sugiura et al., 2006) \\
\hline P. dentata & Catechol \& rutin & $\begin{array}{l}\text { Inhibition of LPS induced NO production in RAW } 264.7 \\
\text { cells }\end{array}$ & (Kazłowska et al., 2010) \\
\hline V. obtusaloba & Vidalols A and B & Inhibition of mouse ear inflammation & $\begin{array}{l}\text { (Wiemer, Idler, \& } \\
\text { Fenical, 1991) }\end{array}$ \\
\hline E. cava & Dieckol & $\begin{array}{l}\text { Inhibition of LPS induced NO production in murine BV2 } \\
\text { microglia }\end{array}$ & (Jung et al., 2009) \\
\hline I. okamurae & Diphlorethohydroxycarmalol & $\begin{array}{l}\text { Down-regulation of iNOS and COX-2 expression and NF-B } \\
\text { activation in human umbilical vein endothelial cells and } \\
\text { RAW } 264.7 \text { cells }\end{array}$ & (Heo et al., 2010) \\
\hline E. stolonifera & Phlorofucofuroeckol A \& B & $\begin{array}{l}\text { Inhibition of NO production by downregulating iNOS and } \\
\text { prostaglandin E2 production in LPS stimulated RAW } \\
264.7 \text { cells }\end{array}$ & (Lee et al., 2012) \\
\hline Ishige foliacea & Octaphlorethol A & $\begin{array}{l}\text { Inhibition of pro-inflammatory cytokines, mitogen- } \\
\text { activated protein kinase and NF-B pathways in CpG- } \\
\text { stimulated macrophage and dendritic cells }\end{array}$ & (Manzoor et al., 2013) \\
\hline \multicolumn{4}{|l|}{ C) Antimicrobial activities } \\
\hline $\begin{array}{l}\text { U. reticulata, C. occidentalis, } C \text {. } \\
\text { socialis, D. ciliolata \& G. } \\
\text { dendroides }\end{array}$ & Rutein, quercetin \& kaempherol & $\begin{array}{l}\text { Inhibiting of Gram-positive and negative bacteria (E. coli, } \\
\text { P. aeruginosa, S.aureus, E. faecalis) }\end{array}$ & (Al-Saif, 2014) \\
\hline $\begin{array}{l}\text { J. rubens, } \text { C. mediterranea, } P . \\
\text { capillacea }\end{array}$ & Phenol, tannin \& flavonoids & Controlling the growth of $V$. fluvialis & $\begin{array}{l}\text { (Mohy El-Din \& El- } \\
\text { Ahwany, 2016) }\end{array}$ \\
\hline E. kurome & $\begin{array}{l}\text { 8'-bieckol, eckol, dieckol, phloroglucinol \& } \\
\text { phlorofucofuroeckol-A }\end{array}$ & $\begin{array}{l}\text { Bactericidal activity (Methicillin-resistant Staphylococcus } \\
\text { aureus (MRSA), B. cereus, C. jejuni, E. coli, S. enteritidis, S. } \\
\text { typhimurium, V. parahaemolyticus) }\end{array}$ & (Ahn et al., 2004) \\
\hline E. bicyclis & $\begin{array}{l}\text { Eckol, dieckol, dioxinodehydroeckol, } \\
\text { fucofuroeckol-A \& phlorofucofuroeckol-A }\end{array}$ & Effective in inhibiting growth (S. aureus \& MRSA) & (Eom et al., 2012) \\
\hline E. cava & Dieckol & Fungicidal activity (T. rubrum) & (Choi et al., 2010). \\
\hline E. cava & Eckol & Potent antimicrobial activity (MRSA) & (Choi et al., 2010). \\
\hline $\begin{array}{l}\text { C. rubrum, S. vulgare, S. fusiforme \& } \\
\text { P. pavonia }\end{array}$ & Phenols & Antimicrobial activity (S. aureus \& K. pneumoniae) & (El Shafay et al., 2016) \\
\hline
\end{tabular}

antioxidant capacity. Thus, this group of phenols has been studied to prevent carcinogenic processes (Jiang \& Shi, 2018). Some of the results obtained in these studies can be observed in Table 3 (Part A).

The cytotoxic activity of extract obtained from the red macroalga Polysiphonia lanosa (Linnaeus) Tandy was evaluated using two colon cell lines, known as DLD-1 and HCT-116. Extracts of this alga were previously characterized using GC-MS showing the presence of lanosol and some derivatives such as ethyl ether, an aldehyde, methyl ether, and an $n$-propyl ether. From these compounds, they were synthesized some additional ones. The structural determination of all these molecules allowed relating some chemical structures with their cytotoxicity. The factors that triggered the cytotoxic effects were the number and position of the bromine substituent, the number of phenolic groups, and the presence of $n$-propyl ether derivatives in the side chain. The molecules containing all these chemical structures were those showing the strongest mortality against DLD-1 cells. In the case of this study, it was a synthetic compound named 3c, which increased with longer exposition times up to $24 \mathrm{~h}$ with an $\mathrm{IC}_{50}$ of $2.7 \mu \mathrm{M}$. When all the molecules were tested against HCT-116 cells the same $3 \mathrm{c}$ compound was the most active one however the $n$-propyl ether of lanosol showed a cytotoxicity 10 -fold higher than that observed with DLD-1 cells (Shoeib et al., 2004). These results underline the importance of studying the effect of the molecules in different in vitro cell lines to identify the best target molecule for each carcinogenic model. That is the case of a study in which up to three carcinogenic cell lines were used to evaluate the specificity of the cytotoxic and anti-proliferative effects of 27 marine algae species. Extracts from 14 species of Rhodophyta, 8 of Chlorophyta, and 5 of Phaeophyta were obtained using a solution of dichloromethane:ethanol (7:3) and evaluated against three cancer cell lines: human laryngeal carcinoma (Hep-2) cells, human cervical adenocarcinoma (HeLa) cells, and human nasopharyngeal carcinoma (KB) cells. Udotea flabellum (J.Ellis \& Solander) M.Howec, Udotea conglutinata (J.Ellis \& Solander) J.V.Lamouroux (belonging to the genus Chlorophyta) and Bryothamnion triquetrum (S.G.Gmelin) M.Howe (Rhodophyta) showed low IC $_{50}$ values, thus the application of their extracts in low concentrations represent high cytotoxic effects against of the Hep-2 cell line (IC ${ }_{50}$ of $22.5,22.2$ and $8.2 \mu \mathrm{g} / \mathrm{mL}$ respectively). Similar $\mathrm{IC}_{50}$ values were found for the brown algae extracts obtained from Lobophora variegata (J.V.Lamouroux) Womersley ex E.C.Oliveira and Dictyota caribaea Hörnig \& Schnetter when tested against KB cells ( IC $_{50}$ of 26.2 and $27.9 \mu \mathrm{g} / \mathrm{mL}$ respectively) (Moo-Puc, Robledo, \& Freile-Pelegrín, 2009). In other studies different species of brown (Scytosiphon lomentaria (Lyngbye) 
Link, Padina pavonica (Linnaeus) Thivy, and Cystoseira mediterranea Sauvageau) and red algae (Hypnea musciformis (Wulfen) J.V.Lamouroux and Spyridia filamentosa (Wulfen) Harvey and brown algae species have been assayed against different tumor cell lines, such as the human breast adenocarcinoma (MCF-7) and the human prostate carcinoma epithelium like (DU-145, LNCaP, and PC3). Extracts obtained with dichloromethane, chloroform, and ethanol of $\mathrm{H}$. musciformis achieved cytotoxic activity Extracts from $S$. filamentosa, $C$. mediterranea and $P$. pavonica showed reasonable cytotoxic activities against all the carcinogenic cell lines. The strongest effect was observed when treating cells with $S$. filamentosa extract at a concentration of $100 \mu \mathrm{g} / \mathrm{mL}$ for $24 \mathrm{~h}$. In these conditions, it was demonstrated to reduce the cell viability of the four cell cultures at levels lower than $20 \%$ using, except for LNCap that reduce it up to $40 \%$. In the case of $C$. mediterranea and $P$. pavonica, the viability of the cells was reduced to this same level (40\%) when treating them for $48 \mathrm{~h}$ with extract at concentrations of $200 \mu \mathrm{g} / \mathrm{mL}$ (Taskin, Caki, Ozturk, \& Taskin, 2010). In other work, the same the human breast adenocarcinoma (MCF-7) together with other models such as the promyelocytic leukemia (HL-60) or myelogenous leukemia (K562) cells were used to test the cytotoxicity of two species collected from the coast of Hong Kong, Hydroclathrus clathratus (C.Agardh) M.Howe and Padina arborescens Holmes. Aqueous extracts could inhibit the growth of both carcinogenic culture cell models, MCF-7 and HL-60, without producing high toxicity in non-tumor cells. Although, the most promising result was that obtained with a dichloromethane extract obtained from $H$. musciformis, which showed an $\mathrm{IC}_{50}$ of $3.8 \mu \mathrm{g} / \mathrm{mL}$ against $\mathrm{K} 562$ cells, improving even the $\mathrm{IC}_{50}$ values achieved by the control substance, the etoposide (Wang, Liang, Astronomo, Hsu, Hsieh, Burton, \& Wong, 2008).

Some authors point out that phenolic compounds can inhibit the telomerase activity of tumor cells by suppressing their expression, thus achieving an anticancer effect (Guedes et al., 2013).

\subsection{Antimicrobial properties}

Antimicrobial activities are another well-known bioactivity related to phenolic compounds, as the scientific literature shows and we discuss below. Extracts obtained from different algae species belonging to Chlorophyta (Ulva reticulata Forsskål, Caulerpa occidentalis (J. Ag.) Boergs and Cladophora social Kützing), Phaeophyta (Dictyota ciliolata Sonder ex Kützing), and a Rhodophyta (Gracilaria dendroides Gargiulo, De Masi \& Tripodi), were tested against pathogenic bacteria, both Gram-positive and Gram-negative: Escherichia coli, Pseudomonas aeruginosa, Staphylococcus aureus, and Enterococcus faecalis. Different solvents (ethanol, chloroform, petroleum ether, and water) were used to perform the extractions. The highest and most significant antibacterial activity was achieved using chloroform extracts of all the five species, followed by ethanolic ones. All the five chloroform-based extracts showed a stronger effective inhibition of the growth of $E$. coli and $P$. aeruginosa than for $S$. aureus and $E$. faecalis. Growth was inhibited by all these extracts, except that obtained from $C$. occidentalis. An interesting result is that ethanol and chloroform extracts of the five species recorded stronger inhibitory activities against $E$. coli than that for ampicillin. In general terms, regarding the most effective species, the results pointed to the red algae $G$. dendroides, followed by $U$. reticulata, and thirdly, the brown algae $D$. ciliolata. The phenolic compounds rutein, quercetin, and kaempherol, each one belonging to the flavonoid group, were present in all the extracts obtained and were the compounds responsible for this antimicrobial capacity (Al-Saif, 2014). Other studies are in line with these results, showing that other phenolic compounds possess the capacity of inhibiting the growth of different pathogenic microorganisms. The antimicrobial capability of three different algae species, Jania rubens (Linnaeus) J.V.Lamouroux, C. mediterranea, and Pterocladiella capillacea (S.G.Gmelin) Santelices \& Hommersand, was analyzed testing different solvents (methanol, ethanol, acetone, and chloroform) against Vibrio fluvialis using the halo inhibition method on agar assay. The flavonoid content for these algae was established in a range from 0.12 to $0.46 \mathrm{mg} / \mathrm{g}$ and associated with their antimicrobial activity. The methanolic extracts were the ones that achieved greater inhibition of the growth of $V$. fluviales, followed by the ethanolic extracts and, finally, the acetone extracts. Likewise, the extracts obtained from $P$. capillacea achieved greater inhibition halos than those obtained from the other algae, proving that they contained mostly beneficial fatty acids, as well as 1,2-benzenedicarboxylic acid (Mohy El-Din \& ElAhwany, 2016).

Other relevant molecules, also belonging to phenolic compounds and present in seaweed, are phlorotannins. Numerous extracts rich in these substances have been studied. As an example, phlorotannins extracted from Ecklonia kurome Okamura (8,8'-bieckol, eckol, dieckol, phlorofucofuroeckol-A and phloroglucinol) were found to have bactericidal effects against a wide range of pathogenic microorganisms of current relevance, such as methicillin-resistant S.aureus (MRSA), Bacillus cereus, Campylobacter jejuni, E. coli, Salmonella enteritidis, Salmonella typhimurium, and Vibrio parahaemolyticus. After that, in vivo assays were performed to discard toxic effects. The daily oral administration of doses between 170 and $1500 \mathrm{mg}$ of phlorotannins per $\mathrm{kg}$ of body weight for 14 days did not produce significant toxic adverse effects in mice. Regarding the mechanism of action, phlorotannins have a harmful effect on bacterial proteins, preventing their growth (Nagayama, Iwamura, Shibata, Hirayama, \& Nakamura, 2002). Phlorotannins were also found in E. bicyclis, specifically eckol, dieckol, dioxinodehydroeckol, fucofuroeckol-A, 7-phloroeckol and phlorofucofuroeckol-A. These compounds showed $\mathrm{IC}_{50} 32-64 \mu \mathrm{g} / \mathrm{mL}$ against S. aureus and MRSA (Eom et al., 2012b).

Phenolic compounds found in algae have also been demonstrated to possess antifungal properties, as reported by some studies performed with dieckol and eckol extracted and purified from E. cava. Both compounds achieved a potent antifungal activity against Trichophyton rubrum Malmsten induced by two different mechanisms of action: the inhibition of cell metabolism and the disordered cell membrane. Besides, the minimum inhibitory concentration (MIC) against MRSA was between 125 and $250 \mu \mathrm{g} / \mathrm{mL}$ (Choi et al., 2010; Lee, Lee, Oh, Lee, \& Chee, 2010).

Table 3 compiles additional examples in which extracts obtained from a wide variety of algae have been evaluated as antimicrobial agents and show how phenolic compounds with different chemical natures achieve potent antibacterial activities against a wide range of microorganisms of current clinical importance (Table 3 part B). Currently, antibiotic resistance represents a worldwide threat to human and animal health. Therefore, phenolic compounds, or synergistic combinations thereof with other substances, such as fatty acids, halogenated compounds or terpenes, offer possible renewed solutions to combat the microbial resistance to antibiotics that arise (El Shafay, Ali, \& El-Sheekh, 2016; Lee et al., 2014)

\subsection{Anti-inflammatory properties}

Marine algae are responsible for many anti-inflammatory products on the market over the last few years (Abad, 2013). Phlorotannins, present in brown algae, are particularly important for this bioactivity because they are pro-inflammatory cytokines inhibitors capable of acting in lipopolysaccharides (LPS) stimulated microglial cells as inducible nitric oxide synthase (iNOS), cyclooxygenase-2 (COX-2), tumor necrosis factor-alpha (TNF- $\alpha$ ), interleukin- 1 beta (IL-1 $\beta)$ and interleukin-6 (IL-6) (Fernando et al., 2016; Ryu \& Kim, 2012).

Extracts of Porphyria dentata C.Agardh, a red edible seaweed are known worldwide in folk medicine for the treatment of various inflammatory diseases, has been also studied. Some of the phenolic compounds that were identified were hesperidin, rutin, and catechol. The extract containing these compounds inhibited the production of NO in LPS-stimulated RAW 264.7 cells. They also tested the isolated compounds by themselves and catechol proved to be a potent suppressor of 
the up-regulation of iNOS promoter and NF- $\mathrm{KB}$ enhancer. It had a lot better results than rutin and hesperidin alone was unable to inhibit either activity (Kazłowska, Hsu, Hou, Yang, and Tsai (2010).

Vidalia obtusiloba (Mertens ex C.Agardh) J.Agardh is also a red alga that contains phenolic compounds with anti-inflammatory proprieties. Bromophenolic metabolites were isolated from this alga, namely vidalols A 313 and B 314 that act as anti-inflammatory compounds by inhibiting the phospholipase A2 enzyme. Table 3 (part C) summarizes the phenolic compounds that have been isolated from algae and their antiinflammatory activities (El Gamal (2010).

\subsection{Other bioactivities}

Dieckol is also associated with antidiabetic proprieties. When testing dieckol extracted from brown seaweed, (Kang et al., 2013) discovered that it also had antidiabetic potential because the levels of blood glucose, serum insulin, and body weight diminished when compared to a diet containing this molecule with a control (without dieckol).

Another study tested $A$. nodosum extracts and their capability to inhibit $\alpha$-glucosidase and $\alpha$-amylase. These proteins are responsible for starch digestion and blood glucose regulation and they are key enzymes that, thus act at very low levels. The extracts from this edible seaweed contained up to $4.5 \mathrm{mg} / \mathrm{g}$ DW and showed very effective inhibition of the $\alpha$-amylase activity with an $\mathrm{IC}_{50}$ of $0.1 \mu \mathrm{g} / \mathrm{ml} \mathrm{GAE}$ while it displayed a higher $I C_{50}, 20 \mu \mathrm{g} / \mathrm{ml} \mathrm{GAE}$, for the inhibition of the $\alpha$-glucosidase The low concentrations that these extracts require to inhibit enzymatic activities are easily achievable in the gut. Therefore, they represent an affordable alternative to other anti-diabetic drugs (Nwosu et al. (2011).

Algae extracts from E. stolonifera containing phlorotannin, dieckol, and eckol were studied, resulting in possessing antihypolipidemic activities. These compounds were tested in hyperlipidemic rats and were able to significantly reduce the levels of LDL cholesterol, total cholesterol, and triglyceride, and significantly increase the level of HDL cholesterol (Yoon, Kim, Chung, and Choi (2008).

Marine organisms like algae are very exposed to extreme solar radiation. Their defense mechanism is the production of a large variety of photo-protective and anti-photoaging compounds. These compounds are capable of absorbing UV-A and UV-B rays and some of them can even scavenge the ROS produced and inhibit the formation of free radicals. Several extracts from different marine algae shown photo-protective functions and these extracts were rich in phenolic compounds like shinorine, porphyra-334, palythene, eckstolonol, eckol, sargachromenol, tetraprenyltoluquinol chromane meroterpenoid, scytonemin, and sargaquinoic acid, all compounds with photo-protective capacity (H. D. Wang, Li, Lee, \& Chang, 2017).

Eckstolonol isolated from E. cava was also tested, proving that this phenolic compound was able to protect HaCat cells from photo-oxidative stress. Eckstolonol $(200 \mu \mathrm{M})$ was shown to repair the damage produced by the UV-B rays due to the activation of catalase and superoxide dismutase enzymes by removing the increased ROS (Jang et al. (2012).

Phenolic compounds extracted from marine algae also demonstrated antiviral activity, specifically anti-HIV compounds. (Ahn et al., 2004) isolated two phlorotannins, 8,8'-bieckol and 8,4'"-dieckol, and these have shown an inhibitory effect on HIV-1 reverse transcriptase and protease in vitro. 6,6'-Bieckol, a phloroglucinol derivate, extracted from $E$. cava also shown to be a potent inhibitor against HIV-1 and induced syncytia formation, lytic effects, and viral p24 antigen production in vitro and in cellular experiments. Additionally, it was able to inhibit the activity of HIV-1 reverse transcriptase enzyme with an $\mathrm{IC}_{50}$ of $1.07 \mu \mathrm{M}$, presenting no cytotoxicity at the tested concentrations where it has inhibited HIV-1 replication almost completely (Artan et al., 2008).

\section{Conclusions and further prospects}

A wide variety of compounds extracted from seaweed are currently used in various commercial product groups as functional food ingredients, as natural nutraceuticals obtained from marine environments, as biomedical materials, in cosmetic preparations, as well as in other products that promote human health (Sun et al., 2018).

The application of phenolic compounds extracted from algae as functional ingredients could also offer new opportunities to continue developing products for therapeutic, palliative or prophylactic purposes, which have beneficial effects on human health. These facts, together with the growing consumers demand of products of natural origin, have aroused great interest in the industries, particularly in the food, pharmaceutical and cosmetic industries, make algae an ideal natural matrix from which to extract phenolic compounds for purposes of industrial application, so that they behave as natural ingredients that replace synthetic ones, associated with certain disorders or allergies, or as active and functional ingredients that provide beneficial health effects. Besides, algae can be easily obtained, since their cultivation through aquaculture is currently booming and increasingly being optimized, so that it is easy, fast, economic and productive, compared to the cultivation of land plants. Although "algaquaculture", as some authors define the cultivation of algae, is mainly focused on the production of algae with alimentary purposes, it could be also advantageous to produce algae to extract bioactive compounds from them, such as phenolic compounds. Another option to obtain those beneficial molecules could be the use of invasive algae species that migrate to other areas causing environmental and economic damages, so they must be removed and eliminated.

Furthermore, algae contain certain phenolic compounds that are exclusively found in them in nature, phlorotannins. Those are responsible of the exertion of bioactivities whose use could improve the human health, raising algae value and uniqueness as raw natural material. Although algae constitute a highly widespread renewable resource, most seaweed are underexploited and processed into fertilizers and animal feeds. Pre-processing operations and extraction processes conditions play important roles in improving or reducing the phenolic compounds content, thus altering their health benefits. This review collects the most recent applied techniques to extract phenolic compounds and the suitable conditions of the different variables involved to avoid losses and guarantee their stability; as well as a classification of the phenolics found in algae and a description of the biological properties associated with them. Regarding phenolic compounds' identification and quantification, most studies report their results as "total phenolic compounds", instead of providing a list of the specific molecules, since their identification is still difficult due to the lack of information concerning this area.

Therefore, algae seem to have a promising future within the pharmaceutical and cosmetic industries (Barlow, Sims, \& Quinn, 2016). However, numerous in vivo analysis beyond rats are necessary, that is, to move into the clinical phases of research so that bioactivities are tested and toxicity tests are conducted on human subjects in search of possible and promising applications of these compounds in different areas concerning the human being's health. Likewise, it would be interesting to elucidate more about phenolic compounds' identification and the specific mechanisms of action associated with the structures of each compound, so that structure-activity relationships that allow molecular modifications can be established to achieve more appropriate characteristics or properties for certain applications.

\section{CRediT authorship contribution statement}

C. Jimenez-Lopez: Writing - original draft. A.G. Pereira: Writing original draft. C. Lourenço-Lopes: Writing - original draft. P. GarciaOliveira: Writing - original draft. L. Cassani: Writing - original draft. M. Fraga-Corral: Writing - original draft. M.A. Prieto: Writing - 
original draft, Conceptualization, Methodology, Writing - review \& editing. J. Simal-Gandara: Writing - original draft, Conceptualization, Methodology, Writing - review \& editing.

\section{Declaration of Competing Interest}

The authors declare that they have no known competing financial interests or personal relationships that could have appeared to influence the work reported in this paper.

\section{Acknowledgments}

The research leading to these results was funded by FEDER under the program Interreg $\mathrm{V}$ Spain-Portugal by POPTEC, IBERPHENOL Project (ref. 0377-Iberphenol-6-E) and by NANOEATERS Project (ref. 0181-NANOEATERS-01-E) that supports the pre-doctoral work of C. Jimenez-Lopez; by MICINN supporting the Ramón\&Cajal grant for M.A. Prieto (RYC-2017-22891); by Xunta de Galicia and University of Vigo supporting the post-doctoral grant for M. Fraga-Corral (ED481B-2019/ 096), and the pre-doctoral grants for A.G. Pereira (ED481A-2019/0228) and P. García-Oliveira (ED481A-2019/295); by the company AlgaMar (www.algamar.com) and Axudas Conecta Peme (Xunta de Galicia) supporting the IN852A 2018/58 NeuroFood Project that financed the pre-doctoral grant for C. Lourenço-Lopes; Ibero-American Program on Science and Technology (CYTED - AQUA-CIBUS, P317RT0003) and UP4HEALTH Project (H2020-BBI-JTI-2019) for financial support. Lucía Cassani thanks the Secretaría General Iberoamericana (SEGIB) Fundación Carolina for a grant.

\section{References}

Abad, M. J. (2013). Anti-inflammatory properties of algae. Functional Ingredients from Algae for Foods and Nutraceuticals (pp. 338-368). Woodhead Publishing Limited. Acosta-Estrada, B. A., Gutiérrez-Uribe, J. A., \& Serna-Saldívar, S. O. (2014). Bound phenolics in foods, a review. Food Chemistry, 152, 46-55.

Agregán, R., Munekata, P. E. S., Franco, D., Dominguez, R., Carballo, J., \& Lorenzo, J. M. (2017). Phenolic compounds from three brown seaweed species using LC-DAD-ESIMS/MS. Food Research International, 99, 979-985.

Ahn, M. J., Yoon, K. D., Min, S. Y., Lee, J. S., Kim, J. H., Kim, T. G., ... Kim, J. (2004) Inhibition of HIV-1 reverse transcriptase and protease by phlorotannins from the brown alga Ecklonia cava. Biological and Pharmaceutical Bulletin, 27(4), 544-547.

Aires, A. (2017). Phenolics in Foods: Extraction, Analysis and Measurements. In Phenolic Compounds - Natural Sources, Importance and Applications (pp. 61-88).

Al-Saif, S. S. A. llah, Abdel-Raouf, N., El-Wazanani, H. A., \& Aref, I. A. (2014). Antibacterial substances from marine algae isolated from Jeddah coast of Red sea, Saudi Arabia. Saudi Journal of Biological Sciences, 21(1), 57-64.

Artan, M., Li, Y., Karadeniz, F., Lee, S. H., Kim, M. M., \& Kim, S. K. (2008). Anti-HIV-1 activity of phloroglucinol derivative, 6,6'-bieckol, from Ecklonia cava. Bioorganic and Medicinal Chemistry, 16(17), 7921-7926.

Azmir, J., Zaidul, I. S. M., Rahman, M. M., Sharif, K. M., Mohamed, A., Sahena, F., Omar, A. K. M. (2013). Techniques for extraction of bioactive compounds from plant materials: A review. Journal of Food Engineering.

Barbosa-Pereira, L., Bilbao, A., Vilches, P., Angulo, I., Lluis, J., Fité, B., ... Cruz, J. M. (2014). Brewery waste as a potential source of phenolic compounds: Optimisation of the extraction process and evaluation of antioxidant and antimicrobial activities. Food Chemistry, 145, 191-197.

Barlow, J., Sims, R. C., \& Quinn, J. C. (2016). Techno-economic and life-cycle assessment of an attached growth algal biorefinery. Bioresource Technology, 220, 360-368.

Carreto, J. I., \& Carignan, M. O. (2011). Mycosporine-like amino acids: Relevant secondary metabolites. chemical and ecological aspects. Marine Drugs, 9(3), 387-446.

Chatterjee, D., \& Bhattacharjee, P. (2014). Supercritical carbon dioxide extraction of antioxidant rich fraction from Phormidium valderianum: Optimization of experimental process parameters. Algal Research, 3(1), 49-54.

Choi, J. G., Kang, O. H., Brice, O. O., Lee, Y. S., Chae, H. S., Oh, Y. C., ... Kwon, D. Y. (2010). Antibacterial activity of Ecklonia cava against methicillin-resistant Staphylococcus aureus and Salmonella spp.. Foodborne Pathogens and Disease.

Ciko, A. M., Jokić, S., Šubarić, D., \& Jerković, I. (2018). Overview on the application of modern methods for the extraction of bioactive compounds from marine macroalgae. Marine Drugs, 16(10).

Costa, P., Gonçalves, S., Valentão, P., Andrade, P. B., Almeida, C., Nogueira, J. M. F., \& Romano, A. (2013). Metabolic profile and biological activities of Lavandula pedunculata subsp. lusitanica (Chaytor) Franco: Studies on the essential oil and polar extracts. Food Chemistry, 141(3), 2501-2506.

Da Silva Port's, P., Chisté, R. C., Godoy, H. T., \& Prado, M. A. (2013). The phenolic compounds and the antioxidant potential of infusion of herbs from the Brazilian Amazonian region. Food Research International, 53(2), 875-881.
Dang, T. T., Bowyer, M. C., Van Altena, I. A., \& Scarlett, C. J. (2018). Optimum conditions of microwave-assisted extraction for phenolic compounds and antioxidant capacity of the brown alga Sargassum vestitum. Separation Science and Technology (Philadelphia), 53(11), 1711-1723.

Dang, T. T., Van Vuong, Q., Schreider, M. J., Bowyer, M. C., Van Altena, I. A., \& Scarlett, C. J. (2017). Optimisation of ultrasound-assisted extraction conditions for phenolic content and antioxidant activities of the alga Hormosira banksii using response surface methodology. Journal of Applied Phycology, 29(6), 3161-3173.

Dias, M. I., Sousa, M. J., Alves, R. C., \& Ferreira, I. C. F. R. (2016). Exploring plant tissue culture to improve the production of phenolic compounds: A review. Industrial Crops and Products, 82, 9-22.

El Gamal, A. A. (2010). Biological importance of marine algae. Saudi Pharmaceutical Journal, 18(1), 1-25.

El Shafay, S. M., Ali, S. S., \& El-Sheekh, M. M. (2016). Antimicrobial activity of some seaweeds species from Red sea, against multidrug resistant bacteria. Egyptian Journal of Aquatic Research, 42(1), 65-74.

Eom, S. H., Kim, Y. M., \& Kim, S. K. (2012a). Antimicrobial effect of phlorotannins from marine brown algae. Food and Chemical Toxicology, 50(9), 3251-3255.

Eom, S. H., Lee, S. H., Yoon, N. Y., Jung, W. K., Jeon, Y. J., Kim, S. K., ... Kim, Y. M. (2012b), $\alpha$-Glucosidase- and $\alpha$-amylase-inhibitory activities of phlorotannins from Eisenia bicyclis. Journal of the Science of Food and Agriculture, 92(10), 2084-2090.

Fabrowska, J., Ibañez, E., Łęska, B., \& Herrero, M. (2016). Supercritical fluid extraction as a tool to valorize underexploited freshwater green algae. Algal Research, 19, 237-245.

Fernando, I. P. S., Nah, J. W., \& Jeon, Y. J. (2016). Potential anti-inflammatory natural products from marine algae. Environmental Toxicology and Pharmacology. Elsevier B.V.

Ferreira, I. C. F. R., Martins, N., \& Barros, L. (2017). Phenolic Compounds and its bioavailability: In vitro bioactive compounds or health promoters? Advances in Food and Nutrition Research, 82, 1-44.

Foo, S. C., Yusoff, F. M., Ismail, M., Basri, M., Yau, S. K., Khong, N. M. H., ... Ebrahimi, M. (2017). Antioxidant capacities of fucoxanthin-producing algae as influenced by their carotenoid and phenolic contents. Journal of Biotechnology, 241, 175-183.

Franks, F. (1998). Freeze-drying of bioproducts: Putting principles into practice. European Journal of Pharmaceutics and Biopharmaceutics, 45(3), 221-229.

Freile-Pelegrín, Y., \& Robledo, D. (2013). Bioactive Phenolic Compounds from Algae. In B. Hernández-Ledesma, \& M. Herrero (Eds.). Bioactive Compounds from Marine Foods: Plant and Animal Sources (pp. 113-129). Chichester: John Wiley \& Sons Ltd.

Ganzera, M., \& Sturm, S. (2018). Recent advances on HPLC or MS in medicinal plant analysis. Journal of Pharmaceutical and Biomedical Analysis, 147, 211-233.

Giada, M. de L. R. (2016). Food Phenolic Compounds: Main classes, sources and their antioxidant power. In Intech (Ed.), Oxidative Stress and Chronic Degenerative Diseases - A Role for Antioxidants (Vol. i, p. 13).

Goo, H. R., Choi, J. S., \& Na, D. H. (2010). Quantitative determination of major phlor otannins in Ecklonia stolonifera. Archives of Pharmacal Research, 33(4), 539-544.

Guedes, É. A. C., da Silva, T. G., Aguiar, J. S., de Barros, L. D., Pinotti, L. M., \& Sant'Ana, A. E. G. (2013). Cytotoxic activity of marine algae against cancerous cells. Brazilian Journal of Pharmacognosy, 23(4), 668-673.

Han, D., Zhu, T., \& Row, K. H. (2011). Ultrasonic extraction of phenolic compounds from Laminaria japonica aresch using ionic liquid as extraction solvent. Bulletin of the Korean Chemical Society, 32(7), 2212-2216.

Hartmann, A., Ganzera, M., Karsten, U., Skhirtladze, A., \& Stuppner, H. (2018). Phytochemical and Analytical Characterization of Novel Sulfated Coumarins in the Marine Green Macroalga Dasycladus vermicularis (Scopoli) Krasser. Molecules, 23, 2735. https://doi.org/10.3390/molecules23112735.

Heffernan, N., Smyth, T. J., Fitzgerald, R. J., Soler-Vila, A., \& Brunton, N. (2014). Antioxidant activity and phenolic content of pressurised liquid and solid-liquid ex tracts from four Irish origin macroalgae. International Journal of Food Science and Technology, 49(7), 1765-1772.

Heleno, S. A., Diz, P., Prieto, M. A., Barros, L., Rodrigues, A., Barreiro, M. F., \& Ferreira, I. C. F. R. (2016). Optimization of ultrasound-assisted extraction to obtain mycosterols from Agaricus bisporus L. by response surface methodology and comparison with conventional Soxhlet extraction. Food Chemistry. .

Heo, S. J., Hwang, J. Y., Choi, J. I., Lee, S. H., Park, P. J., Kang, D. H., ... Choi, I. W. (2010). Protective effect of diphlorethohydroxycarmalol isolated from Ishige okamurae against high glucose-induced-oxidative stress in human umbilical vein endothelial cells. Food and Chemical Toxicology, 48(6), 1448-1454.

Herrero, M., Cifuentes, A., \& Ibañez, E. (2006). Sub- and supercritical fluid extraction of functional ingredients from different natural sources: Plants, food-by-products, algae and microalgae - A review. Food Chemistry, 98(1), 136-148.

Herrero, M., Martín-Álvarez, P. J., Señoráns, F. J., Cifuentes, A., \& Ibáñez, E. (2005). Optimization of accelerated solvent extraction of antioxidants from Spirulina platensis microalga. Food Chemistry, 93(3), 417-423.

HongYu, L., Bin, W., ChunGuang, Y., \& YinFeng, X. (2010). Optimization of microwaveassisted extraction of polyphenols from Enteromorpha prolifra by orthogonal test. Chinese Herbal Medicines, 2(4), 321-325.

Ishii, T., Okino, T., Suzuki, M., \& Machiguchi, Y. (2004). Tichocarpols A and B, two novel phenylpropanoids with feeding-deterrent activity from the reel alga Tichocarpus crinitus. Journal of Natural Products, 67(10), 1764-1766.

Jang, J., Ye, B. R., Heo, S. J., Oh, C., Kang, D. H., Kim, J. H., ... Choi, I. W. (2012). Photooxidative stress by ultraviolet-B radiation and antioxidative defense of eckstolonol in human keratinocytes. Environmental Toxicology and Pharmacology, 34(3), 926-934.

Jégou, C., Kervarec, N., Cérantola, S., Bihannic, I., \& Stiger-Pouvreau, V. (2015). NMR use to quantify phlorotannins: The case of Cystoseira tamariscifolia, a phloroglucinolproducing brown macroalga in Brittany (France). Talanta, 135, 1-6.

Jiang, J., \& Shi, S. (2018). 14 - Seaweeds and Cancer Prevention. Bioactive Seaweeds for Food Applications. Elsevier Inc. 
Jung, H. A., Jin, S. E., Ahn, B. R., Lee, C. M., \& Choi, J. S. (2013). Anti-inflammatory activity of edible brown alga Eisenia bicyclis and its constituents fucosterol and phlorotannins in LPS-stimulated RAW264.7 macrophages. Food and Chemical Toxicology, 59, 199-206.

Jung, W. K., Heo, S. J., Jeon, Y. J., Lee, C. M., Park, Y. M., Byun, H. G., ... Choi, I. L. W. (2009). Inhibitory effects and molecular mechanism of dieckol isolated from marine brown alga on COX-2 and iNOS in microglial cells. Journal of Agricultural and Food Chemistry, 57(10), 4439-4446.

Kadam, S. U., Donnell, C. P. O., Rai, D. K., Hossain, M. B., Burgess, C. M., Walsh, D., \& Tiwari, B. K. (2015a). Laminarin from Irish brown seaweeds Ascophyllum nodosum and Laminaria hyperborea: Ultrasound assisted extraction, characterization and bioactivity. Marine Drugs, 13, 4270-4280.

Kadam, S. U., Tiwari, B. K., Smyth, T. J., \& O’Donnell, C. P. (2015b). Optimization of ultrasound assisted extraction of bioactive components from brown seaweed Ascophyllum nodosum using response surface methodology. Ultrasonics Sonochemistry, 23, 308-316.

Kalil, S. J., Moraes, C. C., Sala, L., \& Burkert, C. A. V. (2017). Bioproduct Extraction From Microbial Cells by Conventional and Nonconventional Techniques. In Food Bioconversion (Vol. 2, pp. 179-206). Elsevier Inc.

Kang, M. C., Wijesinghe, W. A. J. P., Lee, S. H., Kang, S. M., Ko, S. C., Yang, X., ... Jeon, Y. J. (2013). Dieckol isolated from brown seaweed Ecklonia cava attenuates type II diabetes in db/db mouse model. Food and Chemical Toxicology, 53, 294-298.

Kazłowska, K., Hsu, T., Hou, C. C., Yang, W. C., \& Tsai, G. J. (2010). Anti-inflammatory properties of phenolic compounds and crude extract from Porphyra dentata. Journal of Ethnopharmacology, 128(1), 123-130.

Kim, M. M., Ta, Q. Van, Mendis, E., Rajapakse, N., Jung, W. K., Byun, H. G., ... Kim, S. K. (2006). Phlorotannins in Ecklonia cava extract inhibit matrix metalloproteinase activity. Life Sciences, 79(15), 1436-1443.

Kim, S. Y., Kim, E. A., Kang, M. C., Lee, J. H., Yang, H. W., Lee, J. S., ... Jeon, Y. J. (2014). Polyphenol-rich fraction from Ecklonia cava (a brown alga) processing by-product reduces LPS-induced inflammation in vitro and in vivo in a zebrafish model. Algae. https://doi.org/10.4490/algae.2014.29.2.165.

Klejdus, B., Plaza, M., Snóblová, M., \& Lojková, L. (2017). Development of new efficient method for isolation of phenolics from sea algae prior to their rapid resolution liquid chromatographic - Tandem mass spectrometric determination. Journal of Pharmaceutical and Biomedical Analysis, 135, 87-96.

Koivikko, R., Loponen, J., Pihlaja, K., \& Jormalainen, V. (2007). High-performance liquid chromatographic analysis of phlorotannins from the brown alga Fucus vesiculosus. Phytochemical Analysis, 18(4), 326-332.

Komes, D., Belščak-Cvitanović, A., Horžić, D., Rusak, G., Likić, S., \& Berendika, M. (2011). Phenolic composition and antioxidant properties of some traditionally used medicinal plants affected by the extraction time and hydrolysis. Phytochemical Analysis, 22(2), 172-180.

Kumar, N., \& Goel, N. (2019). Phenolic acids: Natural versatile molecules with promising therapeutic applications. Biotechnology Reports, 24.

Larrauri, J. A., Rupérez, P., \& Saura-Calixto, F. (1997). Effect of drying temperature on the stability of polyphenols and antioxidant activity of red grape pomace peels. Journal of Agricultural and Food Chemistry.

Le Lann, K., Jégou, C., \& Stiger-Pouvreau, V. (2008). Effect of different conditioning treatments on total phenolic content and antioxidant activities in two Sargassacean species: Comparison of the frondose Sargassum muticum (Yendo) Fensholt and the cylindrical Bifurcaria bifurcata R. Ross. Phycological Research, 56(4), 238-245.

Lee, H., Kang, C., Jung, E. S., Kim, J. S., \& Kim, E. (2011). Antimetastatic activity of polyphenol-rich extract of Ecklonia cava through the inhibition of the Akt pathway in A549 human lung cancer cells. Food Chemistry, 127(3), 1229-1236.

Lee, J.-H., Eom, S.-H., Lee, E.-H., Jung, Y.-J., Kim, H.-J., Jo, M.-R., ... Kim, Y.-M. (2014). In vitro antibacterial and synergistic effect of phlorotannins isolated from edible brown seaweed Eisenia bicyclis against acne-related bacteria. ALGAE, 29(1), 47-55.

Lee, J. H., \& Kim, G. H. (2015). Evaluation of antioxidant activity of marine algae-extracts from Korea. Journal of Aquatic Food Product Technology, 24(3), 227-240.

Lee, M. H., Lee, K. B., Oh, S. M., Lee, B. H., \& Chee, H. Y. (2010). Antifungal activities of dieckol isolated from the marine brown alga Ecklonia cava against Trichophyton rubrum. Journal of Applied Biological Chemistry, 53(4), 504-507.

Lee, M. S., Kwon, M. S., Choi, J. W., Shin, T., No, H. K., Choi, J. S., ... Kim, H. R. (2012). Anti-inflammatory activities of an ethanol extract of Ecklonia stolonifera in lipopolysaccharide-stimulated RAW 264.7 murine macrophage cells. Journal of Agricultural and Food Chemistry, 60(36), 9120-9129.

Li, Y. X., Wijesekara, I., Kim, S. K., \& Li, Y. (2011). Phlorotannins as bioactive agents from brown algae. Process Biochemistry, 46(12), 2219-2224.

Li, Z., Wang, B., Zhang, Q., Qu, Y., Xu, H., \& Li, G. (2012). Preparation and antioxidant property of extract and semipurified fractions of Caulerpa racemosa. Journal of Applied Phycology, 24(6), 1527-1536.

Lim, Y. Y., \& Murtijaya, J. (2007). Antioxidant properties of Phyllanthus amarus extracts as affected by different drying methods. LWT - Food Science and Technology, 40(9), 1664-1669.

Liu, M., Hansen, P. E., \& Lin, X. (2011). Bromophenols in marine algae and their bioactivities. Marine Drugs, 9(7), 1273-1292.

Lobo, A. M., \& Lourenço, M. (2007). Biossíntese de Produtos Naturais. Lisbon: Lisboa: IST Presse.

Lopes, C. L., Pereira, E., Soković, M., Carvalho, A. M., Barata, A. M., Lopes, V., ... Ferreira, I. C. F. R. (2018). Phenolic Composition and bioactivity of Lavandula pedunculata (Mill.) Cav. samples from different geographical origin. Molecules, 23(5), 1037.

López, C. J., Caleja, C., Prieto, M. A., Sokovic, M., Calhelha, R. C., Barros, L., \& Ferreira, I. C. F. R. (2019). Stability of a cyanidin-3-O-glucoside extract obtained from Arbutus unedo L. and incorporation into wafers for colouring purposes. Food Chemistry, 275(June 2018), 426-438.
Maillard, M. N., \& Berset, C. (1995). Evolution of antioxidant activity during Kilning: Role of insoluble bound phenolic acids of Barley and Malt. Journal of Agricultural and Food Chemistry, 43(7), 1789-1793.

Manzoor, Z., Mathema, V. B., Chae, D., Kang, H. K., Yoo, E. S., Jeon, Y. J., \& Koh, Y. S. (2013). Octaphlorethol a inhibits the CPG-induced inflammatory response by attenuating the mitogen-activated protein kinase and nf-kb pathways. Bioscience, Biotechnology and Biochemistry, 77(9), 1970-1972.

Martins, N., Barros, L., \& Ferreira, I. C. F. R. (2016). In vivo antioxidant activity of phenolic compounds: Facts and gaps. Trends in Food Science and Technology, 48, 1-12.

Mekinić, I. G., Skroza, D., Šimat, V., Hamed, I., Čagalj, M., \& Perković, Z. P. (2019). Phenolic content of brown algae (Pheophyceae) species: Extraction, identification, and quantification. Biomolecules, 9(6), 244. https://doi.org/10.3390/biom9060244.

Mohy El-Din, S. M., \& El-Ahwany, A. M. D. (2016). Bioactivity and phytochemical constituents of marine red seaweeds (Jania rubens, Corallina mediterranea and Pterocladia capillacea). Journal of Taibah University for Science, 10(4), 471-484.

Moo-Puc, R., Robledo, D., \& Freile-Pelegrín, Y. (2009). Actividad citotóxica y antiproliferativa in vitro de macroalgas marinas de Yucatán, México. Ciencias Marinas, 35(4), 345-358.

Nagayama, K., Iwamura, Y., Shibata, T., Hirayama, I., \& Nakamura, T. (2002). Bactericidal activity of phlorotannins from the brown alga Ecklonia kurome. Journal of Antimicrobial Chemotherapy, 50(6), 889-893.

Nwosu, F., Morris, J., Lund, V. A., Stewart, D., Ross, H. A., \& McDougall, G. J. (2011). Anti-proliferative and potential anti-diabetic effects of phenolic-rich extracts from edible marine algae. Food Chemistry, 126(3), 1006-1012.

O'Sullivan, A. M., O'Callaghan, Y. C., O'Grady, M. N., Queguineur, B., Hanniffy, D., Troy, D. J., ... O'Brien, N. M. (2011). In vitro and cellular antioxidant activities of seaweed extracts prepared from five brown seaweeds harvested in spring from the west coast of Ireland. Food Chemistry, 126(3), 1064-1070.

Onofrejová, L., Vašíčková, J., Klejdus, B., Stratil, P., Mišurcová, L., Kráčmar, S., ... Vacek, J. (2010). Bioactive phenols in algae: The application of pressurized-liquid and solidphase extraction techniques. Journal of Pharmaceutical and Biomedical Analysis, 51(2), 464-470.

Otero, P., López-Martínez, M. I., \& García-Risco, M. R. (2019). Application of pressurized liquid extraction (PLE) to obtain bioactive fatty acids and phenols from Laminaria ochroleuca collected in Galicia (NW Spain). Journal of Pharmaceutical and Biomedical Analysis, 164, 86-92.

Pinela, J., Prieto, M. A., Carvalho, A. M., Barreiro, M. F., Oliveira, M. B. P. P., Barros, L., \& Ferreira, I. C. F. R. (2016). Microwave-assisted extraction of phenolic acids and flavonoids and production of antioxidant ingredients from tomato: A nutraceutical-oriented optimization study. Separation and Purification Technology. https://doi.org/10, 1016/j.seppur.2016.03.030.

Plaza, M., Amigo-Benavent, M., del Castillo, M. D., Ibáñez, E., \& Herrero, M. (2010). Facts about the formation of new antioxidants in natural samples after subcritical water extraction. Food Research International, 43(10), 2341-2348.

Popplewell, W. L., \& Northcote, P. T. (2009). Colensolide A: A new nitrogenous bromophenol from the New Zealand marine red alga Osmundaria colensoi. Tetrahedron Letters, 50(49), 6814-6817.

Rodrigues, D., Sousa, S., Silva, A., Amorim, M., Pereira, L., Rocha-Santos, T. A. P., Freitas, A. C. (2015). Impact of enzyme- and ultrasound-assisted extraction methods on biological properties of red, brown, and green seaweeds from the Central West Coast of Portugal. Journal of Agricultural and Food Chemistry, 63(12), 3177-3188.

Roh, M. K., Uddin, M. S., \& Chun, B. S. (2008). Extraction of fucoxanthin and polyphenol from Undaria pinnatifida using supercritical carbon dioxide with co-solvent. Biotechnology and Bioprocess Engineering, 13(6), 724-729.

Rojas, J., \& Buitrago, A. (2019). Antioxidant activity of phenolic compounds biosynthesized by plants and its relationship with prevention of neurodegenerative diseases. Bioactive Compounds (pp. 3-31). Elsevier Inc.

Rosic, N. N., Braun, C., \& Kvaskoff, D. (2015). Extraction and Analysis of MycosporineLike Amino Acids in Marine Algae. (D. B. Stengel \& S. Connan, Eds.), Natural Products From Marine Algae: Methods and Protocols. New York: Springer.

Ryu, B. M., \& Kim, S. K. (2012). Pharmacological potential of phlorotannins from marine brown algae. In Marine Pharmacognosy: Trends and Applications.

Sánchez-Camargo, A. D. P., Montero, L., Stiger-Pouvreau, V., Tanniou, A., Cifuentes, A., Herrero, M., \& Ibáñez, E. (2016). Considerations on the use of enzyme-assisted extraction in combination with pressurized liquids to recover bioactive compounds from algae. Food Chemistry, 192, 67-74.

Sánchez-Camargo, A. del P., Ibáñez, E., Cifuentes, A., \& Herrero, M. (2017). Bioactives obtained from plants, seaweeds, microalgae and food by-products using Pressurized Liquid Extraction and Supercritical Fluid Extraction. Comprehensive Analytical Chemistry, 76, 27-51.

Santos-Buelga, C., Gonzalez-Manzano, S., Dueñas, M., \& Gonzalez-Paramas, A. M. (2012), Extraction and isolation of phenolic compounds. Natural Products Isolation, Methods in Molecular Biology, 864(12), 427-464.

Santos, E. S., Abreu, M. M., \& Saraiva, J. A. (2016). Multielemental concentration and physiological responses of Lavandula pedunculata growing in soils developed on different mine wastes. Environmental Pollution, 213, 43-52.

Shi, D., Li, J., Guo, S., Su, H., \& Fan, X. (2009). The antitumor effect of bromophenol derivatives in vitro and Leathesia nana extract in vivo. Chinese Journal of Oceanology and Limnology, 27(2), 277-282.

Shoeib, N. A., Bibby, M. C., Blunden, G., Linley, P. A., Swaine, D. J., Wheelhouse, R. T., \& Wright, C. W. (2004). In-vitro cytotoxic activities of the major bromophenols of the red alga Polysiphonia lanosa and some novel synthetic isomers. Journal of Natural Products, 67(9), 1445-1449.

Sithranga Boopathy, N., \& Kathiresan, K. (2013). Anticancer Agents derived from Marine Algae. Functional Ingredients from Algae for Foods and Nutraceuticals (pp. 307-337). Woodhead Publishing Limited. 
Sugiura, Y., Matsuda, K., Yamada, Y., Nishikawa, M., Shioya, K., Katsuzaki, H., ... Amano, H. (2006). Isolation of a new anti-allergic phlorotannin, phlorofucofuroeckol-B, from an edible brown alga, Eisenia arborea. Bioscience, Biotechnology and Biochemistry, $70(11), 2807-2811$.

Sun, Z., Dai, Z., Zhang, W., Fan, S., Liu, H., Liu, R., \& Zhao, T. (2018). Antiobesity, Antidiabetic, Antioxidative, and Antihyperlipidemic Activities of Bioactive Seaweed Substances. Bioactive Seaweeds for Food Applications (pp. 239-253). Elsevier Inc.

Tanniou, A., Vandanjon, L., Incera, M., Serrano Leon, E., Husa, V., Le Grand, J., ... StigerPouvreau, V. (2014). Assessment of the spatial variability of phenolic contents and associated bioactivities in the invasive alga Sargassum muticum sampled along its European range from Norway to Portugal. Journal of Applied Phycology, 26(2), 1215-1230.

Taskin, E., Caki, Z., Ozturk, M., \& Taskin, E. (2010). Assessment of in vitro antitumoral and antimicrobial activities of marine algae harvested from the eastern Mediterranean sea. African Journal of Biotechnology, 9(27), 4272-4277.

Tierney, M. S., Smyth, T. J., Hayes, M., Soler-Vila, A., Croft, A. K., \& Brunton, N. (2013). Influence of pressurised liquid extraction and solid-liquid extraction methods on the phenolic content and antioxidant activities of Irish macroalgae. International Journal of Food Science and Technology, 48(4), 860-869.

Topuz, O. K., Gokoglu, N., Yerlikaya, P., Ucak, I., \& Gumus, B. (2015). Optimization of Antioxidant Activity and Phenolic Compound Extraction Conditions from Red Seaweed (Laurencia obtuse). Journal of Aquatic Food Product Technology, 25(3), 414-422.

Tsimogiannis, D., \& Oreopoulou, V. (2019). Classification of Phenolic Compounds in Plants. Polyphenols in Plants (pp. 263-284). Elsevier Inc.

Vermerris, W., \& Nicholson, R. (2006). Phenolic compound biochemistry. Phenolic Compound Biochemistry.

Vieira, V., Prieto, M. A., Barros, L., Coutinho, J. A. P., Ferreira, I. C. F. R., \& Ferreira, O. (2018). Enhanced extraction of phenolic compounds using choline chloride based deep eutectic solvents from Juglans regia L. Industrial Crops and Products.

Vuolo, M. M., Lima, V. S., \& Maróstica Junior, M. R. (2019). Phenolic Compounds: Structure, Classification, and Antioxidant Power. In Bioactive Compounds (pp. 33-50). Elsevier Inc.
Wang, H. D., Li, X. C., Lee, D. J., \& Chang, J. S. (2017). Potential biomedical applications of marine algae. Bioresource Technology, 244(May), 1407-1415.

Wang, S. K., Liang, P. H., Astronomo, R. D., Hsu, T. L., Hsieh, S. L., Burton, D. R., \& Wong, C. H. (2008). Targeting the carbohydrates on HIV-1: Interaction of oligomannose dendrons with human monoclonal antibody 2G12 and DC-SIGN. Proceedings of the National Academy of Sciences of the United States of America, 105(10), 3690-3695.

Wiemer, D. F., Idler, D. D., \& Fenical, W. (1991). Vidalols A and B, new anti-inflammatory bromophenols from the Caribbean marine red alga Vidalia obtusaloba. Experientia, 47(8), 851-853.

Wong, K., \& Chikeung Cheung, P. (2001). Influence of drying treatment on three Sargassum species. Protein extractability, in vitro protein digestibility and amino acid profile of protein concentrates. Journal of Applied Phycology, 13(1), 51-58.

Yoon, N. Y., Kim, H. R., Chung, H. Y., \& Choi, J. S. (2008). Anti-hyperlipidemic effect of an edible brown algae, Ecklonia stolonifera, and its constituents on poloxamer 407induced hyperlipidemic and cholesterol-fed rats. Archives of Pharmacal Research, 31(12), 1564-1571.

Yoshie-Stark, Y., \& Hsieh, Y. (2003). Distribution of flavonoids and related compounds from seaweeds in Japan. Tokyo University of Fisheries, 89, 1-6.

Yu, Y., Wang, L., Fu, X., Wang, L., Fu, X., Yang, M., ... Jeon, Y. J. (2019). Anti-oxidant and anti-inflammatory activities of ultrasonic-assistant extracted polyphenol-rich compounds from Sargassum muticum. Journal of Oceanology and Limnology, 37(3), $836-847$.

Yuan, Y., Zhang, J., Fan, J., Clark, J., Shen, P., Li, Y., \& Zhang, C. (2018). Microwave assisted extraction of phenolic compounds from four economic brown macroalgae species and evaluation of their antioxidant activities and inhibitory effects on $\alpha$ amylase, $\alpha$-glucosidase, pancreatic lipase and tyrosinase. Food Research International, 113(May), 288-297.

Zakaria, S. M., \& Kamal, S. M. M. (2016). Subcritical water extraction of bioactive compounds from plants and algae: Applications in pharmaceutical and food ingredients. Food Engineering Reviews, 8(1), 23-34.

Zubia, M., Fabre, E., \& Shannon, C. (2009). Antioxidant and cytotoxic activities of some red algae (Rhodophyta) from Brittany coasts (France). Botenica Marina, 52, 268-277. 